\title{
ロ腔領域における襄胞内容液のディスク電気泳動的ならびにポーラログラフ的研究
}

\author{
柬 理 十三雄

\section{Disc-electrophoretic and polarographic studies on the cystic fluid of the oral region}

\author{
Tomio KanRI
}

\section{I. 緒}

\section{論}

䫇・口腔領域に打ける裂胞の研究に関しては，従来， 臨床学的検索および形態学的立場からの病理組織学的検 索が主流であった。しかし, 近年生化学的梌索方法によ る機能的研究が急速に進みつつある.

本邦に扣けるロ腔領域に発生する裂胞の内容物に関す る生化学的研究としては, 深江の口腔底に発生したいわ ゆる Epidermoidcyste の内容物の, 蛋白, 中性脂肪, コレステリンなどを分析定量した報告1が最初であり， それ以来, 有本 $5^{2)}$, 関屋 $5^{3)}$, 形浦 $5^{4)}$, 久野 $5^{5)}$, 長

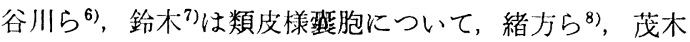

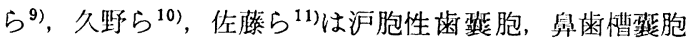
について, ディスク電気泳勘法による蛋白成分の分析, あるいはガスクロマトグラフ法による脂質の分析など， 多角的な分析が陚みられている. しかし，これらの報告 はいずれも，個々の症例についての検索結果をのべたも のであり，それぞれ，分析項目，分析方法に执いて異な るところが多く，各種䌘胞について得られた分析結果か ら，その生物学的意義を考察するには不十分である.

顎・口腔領域にお打る裂胞の成立機序の解明, さらに 臨床的鑑別診断に資する目的のもとに，系統的に賴胞内 容液の生化学的梌索をおこなった研究としては, 吉田 ${ }^{12}$,

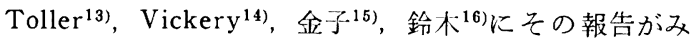
られる. 王として, 整胞内容液の蛋白, 糖, アミノ糖, 脂質 (とくに, コレステロール), 電解質 $(\mathrm{Na}, \mathrm{K}, \mathrm{Cl}$, $\mathrm{P}, \mathrm{Ca}$ ) が定量されているほか, フォスファターゼ, 乳酸 脱水素酸素などの各種醉素の活性が测定されているが,

日本啮科大学新潟幽学部口腔外科学教室第一䍀座 (主任：西村 恒一教授)

First Department of Oral Surgery, Nippon Dental Collge, Niigata Faculty (Chief : Prof. Koichi Nishimura)

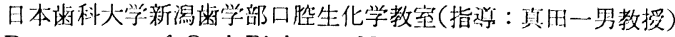
Department of Oral Biology, Nippon Dental Collge, $\mathrm{Ni}$ igata Faculty (Chief : Prof. Kazuo Sanada)

受付 昭和48年10月29日
現在な括不明の点が多い。

䆿胞内容液の蛋白成分についてみると, 総蛋白量では, 函根垶胞に拈いて最も高く，血清とほぼ同值か，もしく はいく分低い值をしめし，沪胞性䨑蒥胞の蛋白含有量は， 歯根裂胞に近いといわれ，これに対し術後性煩部整胞， エナメル上皮腫などの蛋白含有量は低いという ${ }^{15)}$. 蛋白 成分を電気泳動的に分画すると，歯根翌胞では，分子量 の大きい蛋白（たとえば $\alpha$-globulin）が減少，または欠 如するが，分子量の小さい $\gamma$-globulin が血清より高濃 度に含まれていることから，䪼胞壁の組織液成分に対す る選択的透過性，あるいは怔胞壁の組織蛋白の破壊との

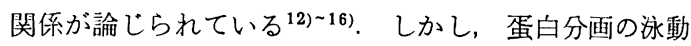
像は，現在まで括こなわれてきた実験方法では，多くの 場合, 分離が不明瞭で, 掛胞内容液に含まれる蛋白成分 の実態を把握するには困難である.

最近, 著者は翼胞内容液に谏結・融解処理を施すこと により，明瞭なディスク電気泳動像が得られることをし った. そこで, 䫇・口腔領域に発生し, 臨床的ならびに 病理組織学的に診断の確定した整胞 6 種22例, 翌胞性工 ナメル上皮腫 2 例, 所属不明の囊胞 3 例の合計27例を選 び，これら琵胞の内容液の蛋白成分をディスク電気泳動 的に梌索するとともに，体液蛋白の性質をしめす一つの 指標として, 癌の診断（癌反応）にも応用されている

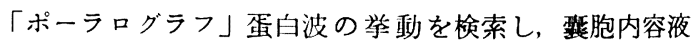
の蛋白組成および電気的特性について，興味ある知見が 得られた.

また，これら鼣胞内容液について，水分，有機成分， 灰分，総蛋白，総脂質扣よびシアル酸の定量を扰こない， 生化学的方法にもとつく型胞胞の臨床的鑑別診断法の可能 性について考察したので報告する.

\section{II. 研究材料と研究方法}

\section{1. 重胞内容液の採取}

日本曾科大学菌学部付属病院口腔外科ならびに同大学 新潟閣学部付属病院口腔外科を訪れた繁胞性疾患患者の 
中から，臨床所見ならびに病理組織学的所見にもとづき 診断の確定した，歯根㯎胞 8 例，沪胞性歯整胞 4 例，術

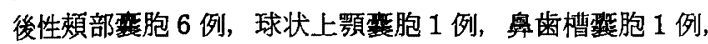
ガマ腫 2 例，エナメル上皮腫（整胞性エナメル上皮腫） 2 例の活か, 診断の確定しなかった「買碃胞」3例の， 合計27例を研究の対象に選び，その内容液を採取して被 検試料に供した.なお，症例の選択に際しては，当該部 位に急性化膿性炎症ならびに穿刺, 切開などの外科的侵 襲の既往を有しないことを条件とした.

雍胞内容液は，20G あるいは23Gの注射針を用いて， 穿刺吸引により採取した．この場合，筳胞の他の一カ所 に注射針のみを刺入して，吸引時に翼胞内が陰王になる ことを防き，内容液に血液が混入しないように，とくに 注意した。採取した内容液は，ただちにー $20^{\circ} \mathrm{C}$ 冷暗所 に密封保存し，用に臨み室温にて解凍した，対照として， 健常青年男子の血液数 $\mathrm{m} l$ を前踠正中皮静脈より採取し， 常法にしたがって血清を分離調製して，秘胞内容液と同 様の分析に供した。

\section{2. ディスク電気泳動}

a 、 ゲル柱の作製

内径 $5 \mathrm{~mm}$, 長さ $100 \mathrm{~mm}$ のディスク電気泳動用カラ ムを用い, Ornstein-Davis の方法 ${ }^{17} に よ る 7.5 \%$ ルリア クリルアミド・ゲルを支持体とする $\mathrm{pH} 9.4$ 用ゲルのカ ラムを調製した．ただし，分離用ゲルならびに濃縮用ゲ ルの長さを，それぞれ $73 \mathrm{~mm}$ 扎よび $17 \mathrm{~mm}$ の一定の長 さになるように注意して調製し，カラムの上端に高さ10 $\mathrm{mm}$ の試料室を設けた.

\section{b. 試料の添加}

一旦凍結保存した霆胞内容液を室温に放置して解谏せ しめ, 不溶成分を $4000 \mathrm{rpm} 5$ 分間遠心分離して除去し たのち，脱イオン水にて10倍に稀釈して試料とした. 血 清は凍結させることなく，新蘚なものを脱イオン水にて 10倍に稀釈し，整胞内容液と同様にあつかった。

濃縮用ゲル調製に用いたTris-塩酸緩衝液（pH 6.7） 1 部に $20 \mathrm{~g} / \mathrm{d} l$ 蔴糖液 3 部を加え混和して試料用蔗糖-緩 衝液を調製し，これに等量の上記垶胞内容液あるいは血 清を添加したのち, 均一に混和して試料溶液とした.

ディク電気泳動に際して，この試料溶夜 $100 \mu l$ を濃 縮用ゲル上の試料室に添加した.

\section{c. 電気泳動}

装置 : 市販のディスク電気泳動装置（管垣医珗科工業, 東京，No. 1467）を用いた。緩衝液槽はプラスチック製 円筒型，電極は白金電極である.

電気泳動：上槽をプラスとして，ゲル管 1 本あたり $5 \mathrm{~mA}$ 通電し, BPB の層 (leading ion の位置) がゲル 管の下端約 $10 \mathrm{~mm}$ の位置まで移動したとき，通電を停 止した.

染色：泳動終了後，たたちにゲル柱をとり出し，1\% Amido black $10 \mathrm{~B}$ 染色液中に, 一夜浸漬したのち, 脱
色液（メタノール:酢酸: 水=25:10:65）中に执いて バックグランドが透明になるまで脱色した。

濃度測定 : 菅垣製自動記録式電気泳動用濃度計 1472-I 型を用い,フィルター $610 \mathrm{~m} \mu$ ，スリット $0.5 \times 3.5 \mathrm{~mm}$, 試料送り速度 $18 \mathrm{~mm} / \mathrm{min}$ で記録した。

3. ポーラロクラフィー

a 試 料

ディスク電気泳動に供試したものの一部を用いた.す なわち、整胞内容液拈よび血清を脱イオン水で10倍に稀 釈したものを試料とした。

b. 溶液条件

1. $2 \times 10^{-2} \mathrm{~mol} \mathrm{CoCl}, 1 N-\mathrm{NH}_{4} \mathrm{Cl}$ お 占び $1 N-\mathrm{NH}_{4} \mathrm{OH}$ の水溶液の各一定量をとり，これに純水の一定量を加光 て目的に応じた一定濃度組成の塩化コパルトを含む塩化 アンモンーアンモニア緩衝液（以後，電解液と呼ぶ）を 調製した。

c 装置执よび蛋白波の記録

島津製・ポーラログラフ装置 RP-50 型を用い,つぎの 条件で蛋白波を記録した．滴下水銀電極を用い， accu一 mulator 2.0 volt, 感度 $50 \mu \mathrm{A} / 200 \mathrm{~mm}$ および $100 \mu \mathrm{A} /$ $200 \mathrm{~mm}$, Damp.3 または 4, 室温において, -0.8 volt から記録をはじめた.な技，波高の湘定はコバルトの拡 散電流から第 1 波拈よび第 2 波の極大部までの電流值を 湘定した。

d. 蛋白波の交叉効果扎よび交叉点

Tropp 5 ${ }^{18)}$ と同様の方法により蛋白波の交叉効果を観 察し，交叉点を求めた。ただし，電解液の組成は $1.2 \times$ $10^{-3} \mathrm{~mol} \mathrm{CoCl}_{2}+0.1 N-\mathrm{NH}_{4} \mathrm{Cl}+0.1 N-\mathrm{NH}_{4} \mathrm{OH}$ とし, 電 解液 $2.0 \mathrm{~m} l$ に試料 $0.1 \mathrm{ml}$ を加兄て最初の蛋白波を記 録したのち，これを順次上記の電解液で稀釈した。

交叉点は電解液中における蛋白濃度（\%）であらわし た.

e. 第一反応（アルカリ変性反応）

試料 $0.1 \mathrm{ml}$ に $0.4 \mathrm{~N}-\mathrm{KOH} 0.1 \mathrm{ml}$ を加え室温に 30 分 間放置したのち東洋沪紙 No. 6 で汇過した。沪液 $0.1 \mathrm{ml}$ を電解液 $\left(2 \times 10^{-3} \mathrm{~mol} \mathrm{CoCl}_{2}+0.2 \mathrm{~N}-\mathrm{NH}_{4} \mathrm{Cl}+0.2 \mathrm{~N}-\right.$ $\left.\mathrm{NH}_{4} \mathrm{OH}\right) 10 \mathrm{~m} l$ に混和してポーラログラムを記録した.

f. 沪液反応

試料 $0.2 \mathrm{ml}$ に $0.2 N-\mathrm{KOH} 0.2 \mathrm{ml}$ を加えて室温に30分 間放置したのち，20\%スルホサリチル酸水溶液 $0.2 \mathrm{~m} l$ を 加えて，さらに10分間放置した。ついで，東洋沪紙 No. 6 で沪過し，沪液 $0.2 \mathrm{ml}$ に電解液（第一反応の場合と同 一組成） $2.0 \mathrm{~m} l$ を加え混和してポーラログラフィーに供 した.

g. Protein index

第一反応の蛋白波の波高（第 2 波の波高）D，扣よび 沪液反応の蛋白波の波高（第 2 波の波高）Fの比に係数 10を乘じて求めた.

すなわち, 


$$
\text { Protein index }=\frac{F}{D} \times 10
$$

をもって表わした.

\section{4. 水分，有機成分および灰分の定量}

十分に空焼きした重量既知のルッボ (14.1035 g $15.9669 \mathrm{~g})$ に裂胞内容液約 $0.3 \mathrm{ml}$ をとり, 重量を計測し て採取した内容液の正確な重量Wを求め, ついで $110^{\circ} \mathrm{C}$ に 4 時間保ち水分を蒸散させたのち, 固形成分の重量 D を正確に計測した。内容液の水分量（\%) は次式で与え られる。

露胞内容液の水分量 $(\%)=\frac{W-D}{W} \times 100$
水分量計測後，ルッボを火焰上において恒温に達する まで赤熱し，冷却後残留した灰分の重量を計測した。

有機成分量は，さきに計測した固形成分の重量から灰 分の重量を差引いて求めた.

\section{5 . 蛋白定量}

牛血清 albumin を対照として，ミクロピューレット 法により，琵胞内容液扣よび血清中の蛋白を定量した.

\section{6. 総ステロールの定量}

Folch のクロロホルム・メタノール $(2: 1 \mathrm{~V} / \mathrm{V})$ 混合 液 $3 \mathrm{~m} l$ に裂胞内容液 $0.1 \mathrm{~m} l$ を加えて振盪混和したの ち, 脂質抽出液（沪液）を内容 $50 \mathrm{ml}$ のナス型フラスコ 中に定量的に集め, $40 \sim 50^{\circ} \mathrm{C}$ の水浴中に打いて減圧乾

表 1 胞内容液の肉眼的所見

\begin{tabular}{|c|c|c|c|c|c|c|c|}
\hline 葆胞の秄類 & $\begin{array}{l}\text { 症例 } \\
\text { 番号 }\end{array}$ & 年令と性別 & 色 調 & 洁罚 & 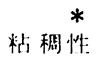 & コレステリン結畾 & 採取量 ( $\mathrm{m} \ell)$ \\
\hline \multirow{8}{*}{ 蔽 根 㠌 胞 } & 1 & 42 , 男 & 淡啰岜 & 泠 & - & - & 1.4 \\
\hline & 2 & 35 ，文 & 淡莎色 & 调 & - & + & 12.7 \\
\hline & 3 & 22, 女 & 茂 色 & 鉴 & + & + & 1.2 \\
\hline & 4 & 42 , 男 & 淡留色 & ilf & - & - & 1.0 \\
\hline & 5 & 31 , 男 & 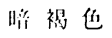 & 滥 & + & - & 2.3 \\
\hline & 6 & 26 , 女 & 洴褐色 & 涺 & - & + & 1.3 \\
\hline & 7 & 21 , 女 & 淡黄色 & 灌 & + & - & 0.9 \\
\hline & 8 & 31 , 男 & 获裸色 & iti & + & - & 0.4 \\
\hline \multirow{4}{*}{ 滤胞性: 菂监泡 } & 9 & 7 , 力 & 花 白 & 罚 & + & - & 1.2 \\
\hline & 10 & 22 , 女 & 橙色 & 罚 & + & - & 1.3 \\
\hline & 11 & 15，女 & 淡范色 & 部 & + & + & 11.2 \\
\hline & 12 & 5 ，男 & 茫色 & 檌 & + & - & 2.4 \\
\hline \multirow{6}{*}{ 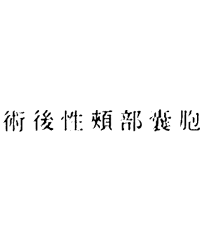 } & 13 & 34 , 女 & 淡萌褐色 & 煔 & + & + & 4.5 \\
\hline & 14 & 71 , 男 & 淡兴色 & 沙明 & - & - & 0.3 \\
\hline & 15 & 22 , 男 & 淡望裸色 & 部 & + & - & 1.3 \\
\hline & 16 & 31 , 男 & 范裀弁 & 淏 & + & - & 0.6 \\
\hline & 17 & 58 ，男 & 淡泋裀色 & il' & + & - & 2.1 \\
\hline & 18 & 34，男 & 栄褐 也 & 罚 & + & - & 2.6 \\
\hline 球状上敫败胞 & 19 & 30 , 男 & 淡趌色 & 洴 & - & + & 0.5 \\
\hline 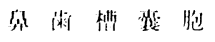 & 20 & 56 , 男 & 势白色 & 滥明 & + & - & 0.4 \\
\hline \multirow{2}{*}{ ガ $\quad \longrightarrow \quad$ 肺 } & 21 & 6 ，男 & 淡蓝色 & 渻 & + & - & 3.2 \\
\hline & 22 & 33 , 多 & 淡范色 & 就 & + & - & 0.2 \\
\hline \multirow{2}{*}{ エナィル1:皮胢 } & 23 & 25，男 & 沙色 & 渴 & + & - & 1.3 \\
\hline & 24 & 41 ，罗 & 淡器色 & ili & - & + & 0.7 \\
\hline \multirow{3}{*}{ 颚 怡 胞 } & 25 & 28 , 次 & 茫裸色 & 滥 & + & - & 6.2 \\
\hline & 26 & 42 , 女 & 淡唄色 & 沙 & - & + & 2.5 \\
\hline & 27 & 33 , 女 & 亚 & 晹 & + & - & 0.5 \\
\hline
\end{tabular}

*垖消よりも明らかに枮秘吽の高いものを十，同程度に感しられたものをーとした。

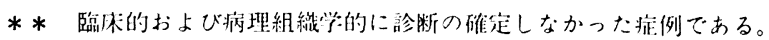

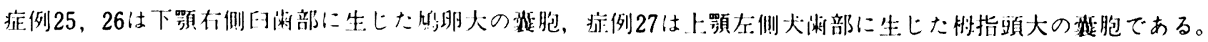


ることが固したものを検体として,Liberman-Burchard 反応により総ステロールの定量をおこなった.

\section{7. シアル酸の定量}

p-Dimethylaminobenzaldehyde 反応によるシアル酸 定量法を用いて，整胞内容液に含まれるシアル酸を定量 した．たたし，溶媒として氷酢酸・過塩素酸混合液を用 いた ${ }^{19)}$.

なお，水分，有機成分，灰分，蛋白，総ステロールお よびシアル酸の定量に際しては, 凍結一融解した賴胞内 容液を均一に振り混ぜたのち, その一定量を試料として 用いた。

\section{III. 研 究 結 果}

\section{1. 莗胞内容液の肉眼的所見}

研究の対象として選択した各種整胞の内容液について, その肉眼的所見を表 1 にまとめた.

歯根琵胞の内容液は, 褐色成分を含むもの 3 例がみと められたが，一般には淡兴色を呈し半透明であった，得 られた内容液の約半数が高い粘稠性を示した. コレステ リン結晶を 8 例中 3 例にみとめた.

沪胞性歯翼胞，ガマ腫およびェナメル上皮腫の内容液 も，歯根褧胞に類似した淡黄色あるいは潢色の色調を呈 し，一般に半透明であり，高い粘稠性を有するものが多 く、コレステリン結晶の浮遊をみとめたものは少なかっ た.

術後性煩部职胞の内容液は褐色を帯び，とくに高い粘 椆性を示す点で，他の揫胞内容液とは異なる所見を示し た. 6 例中 1 例にコレステリン結晶の存在をみとめた.

球状上顎露胞の内容液は淡兴色, 透明で粘稠性は低く, コレステリン結晶をみとめた。

鼻歯槽蓔胞の内容液には、コレステリン結晶はみとめ れず，粘稠性のある透明，薄白色であった。

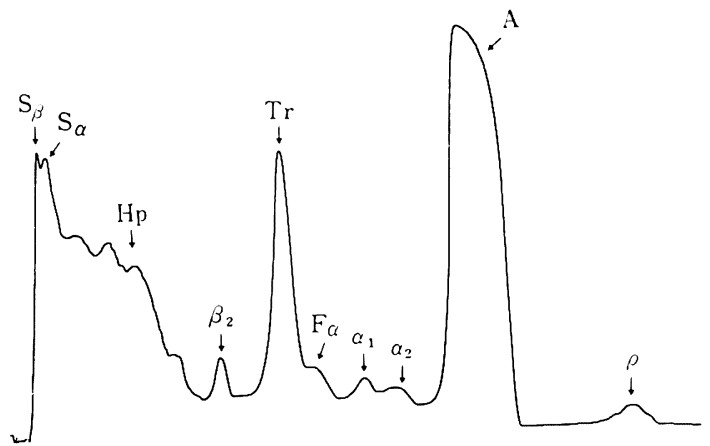

図 1 血清のディスク電気泳糥像 $\rho$ : prealbumin, A : albumin, $\alpha_{1}: \alpha_{1}-$ globulin $の 一$ 部, $\alpha_{2}: \alpha_{2}$-globulin $の 一$ 部, $\mathrm{F}_{\alpha}$ : fast $\alpha_{2}-$ globulin,

Tr : Transferrin, $\beta_{2}: \beta_{2}$-globulin $の 一$ 部,

$\mathrm{Hp}$ : haptoglobin, $\mathrm{S}_{a}$ : slow $\alpha_{2}$-globulin

$\mathrm{S}_{\beta}$ : slow $\beta$-globulin

\section{2. ディスク電気泳動分画}

正常なヒト血清のディスク電気泳動像（以後, 泳動像 と呼ぶ）を，図１にデンシトグラムで示した，画分の名 称は中村にしたがった．同図において， $\rho$ (prealbumin), A (albumin), $\alpha_{1}$ ( $\alpha_{1}-$ globulin), $\alpha_{2}$ ( $\alpha_{2}$-globulin), $\mathrm{F}_{\alpha}$

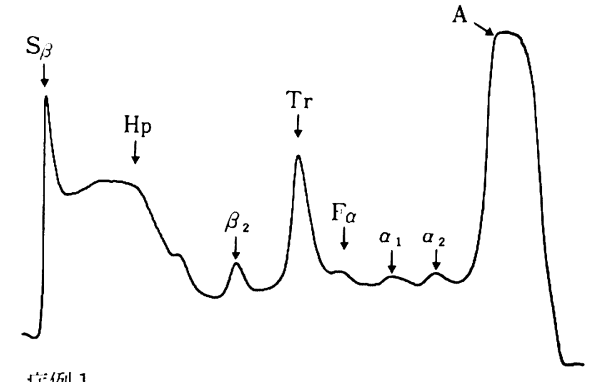

痉例 1

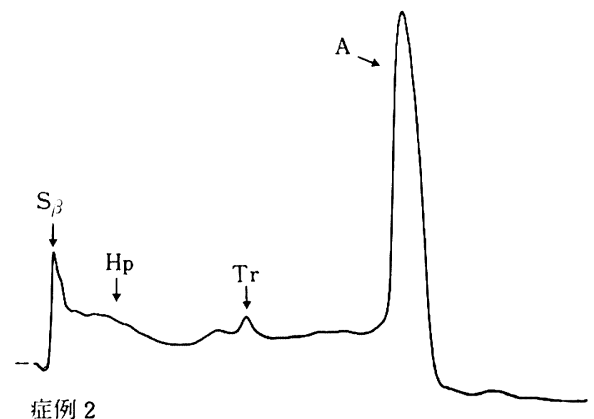

症例 2

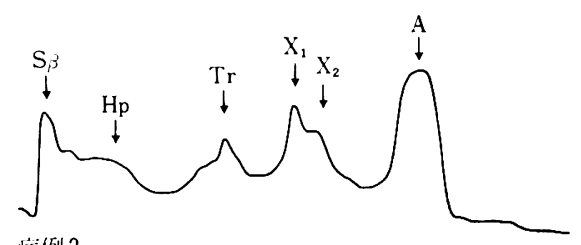

症例 3
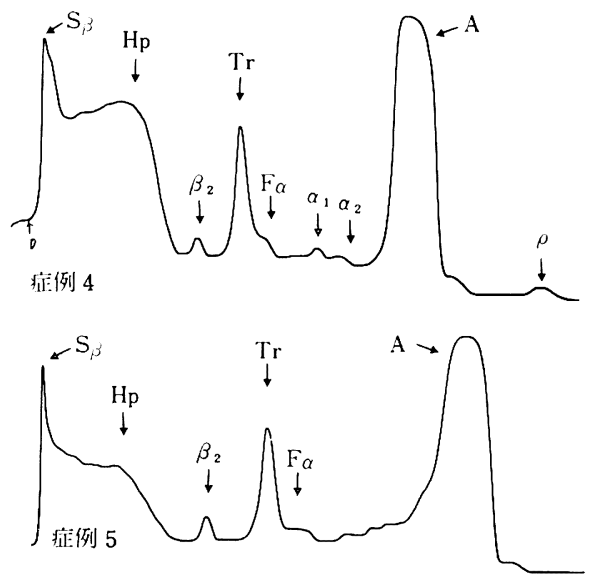

図 2-1 歯恨础胞内容液のディスク電気核秒像 

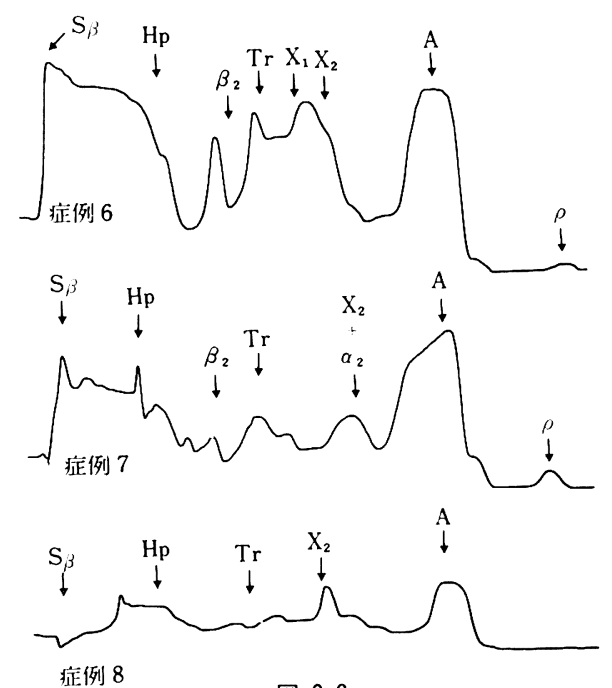

図 2-2

崡根础胞内容液のディスク電気泳動像

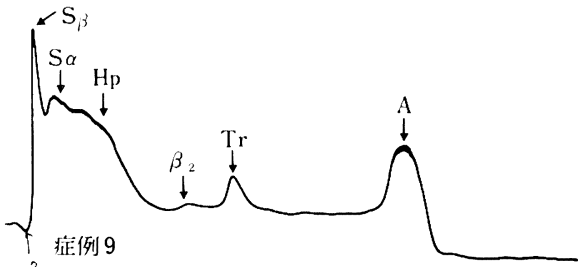
$\mathrm{S}_{i}$,
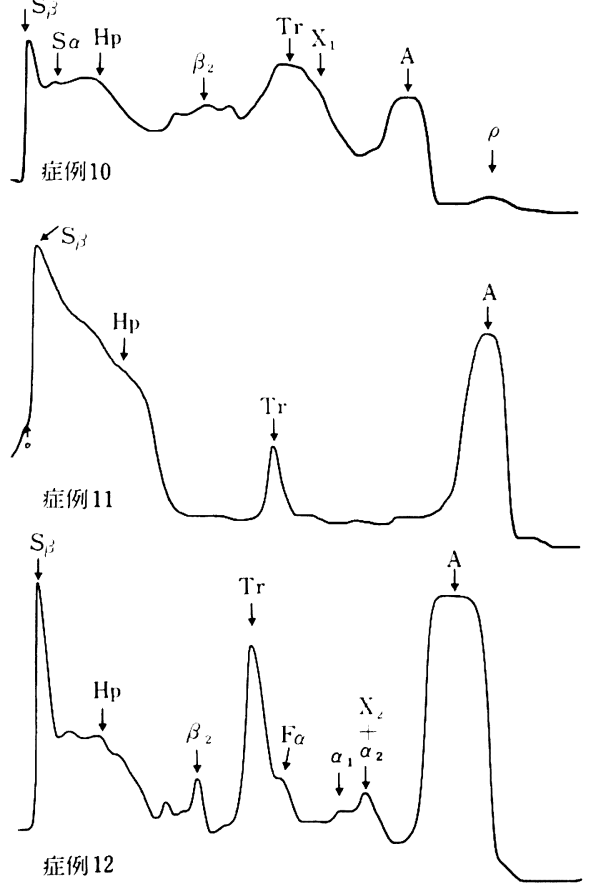

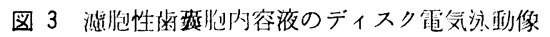

(fast $\alpha_{2}$-globulin), $\operatorname{Tr}$ (transferrin), $\beta_{2}$ ( $\beta_{2}$-globulin) のあきらかな分離がみられるほか，原点にとどまる $S_{\beta}$ (slow $\beta$-globulin), $S_{\alpha}$ (slow $\alpha_{2}$-globulin)および $\beta_{2}$ と $\mathrm{S}_{\alpha}$ の間に不明瞭に分離される $\mathrm{Hp}$ (haptoglobin)を識別す
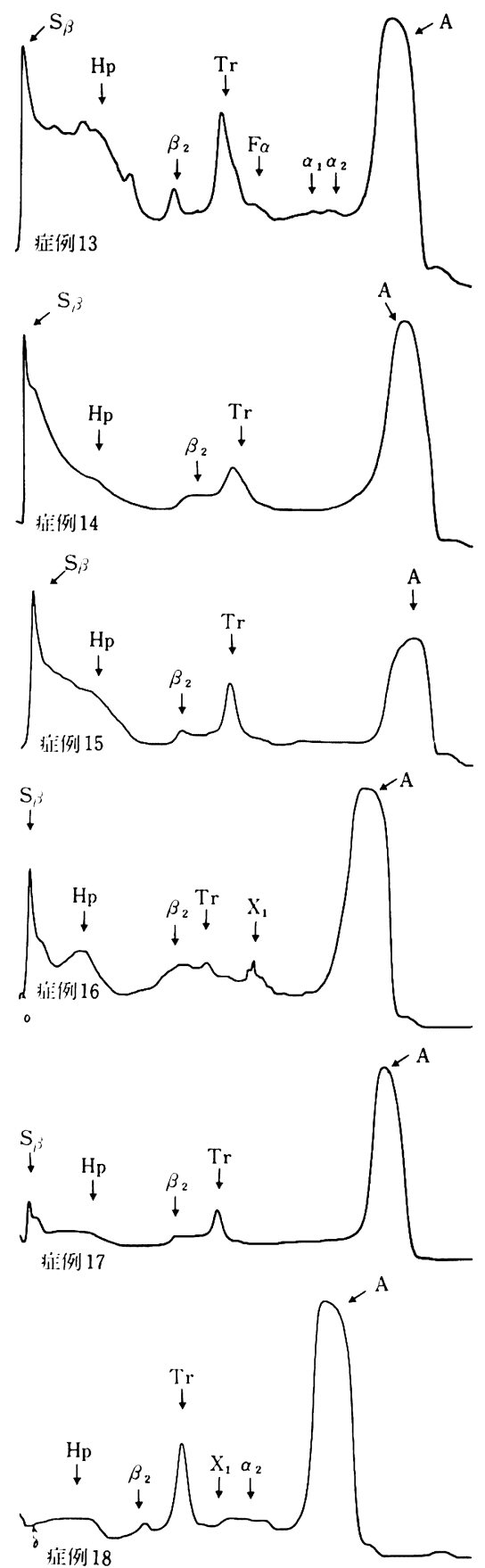

図 4 術後性煩部续胞内容液のディスク電気泳動像 


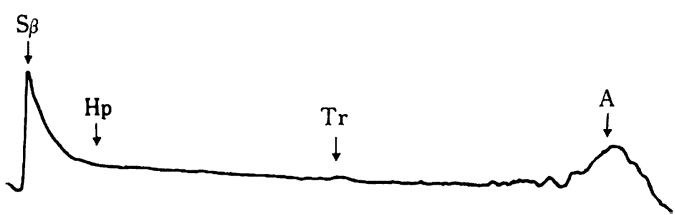

症例 19

図 5 球状上影胞内容液のディスク電気泳動像

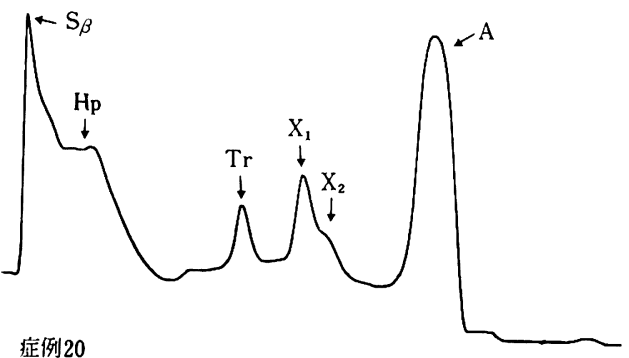

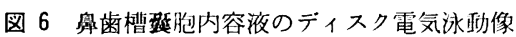
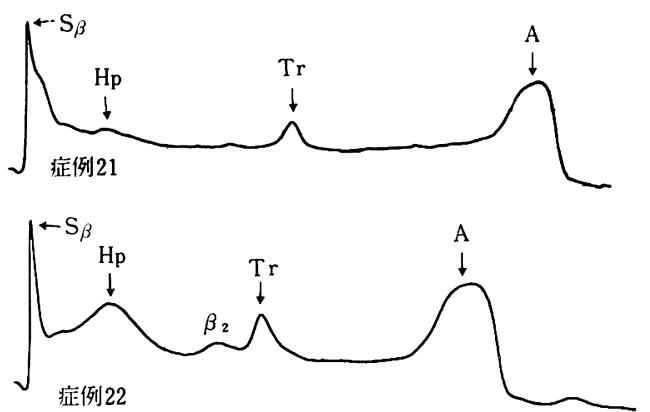

図 7 ガマ腄内容液のディスク電気泳得像

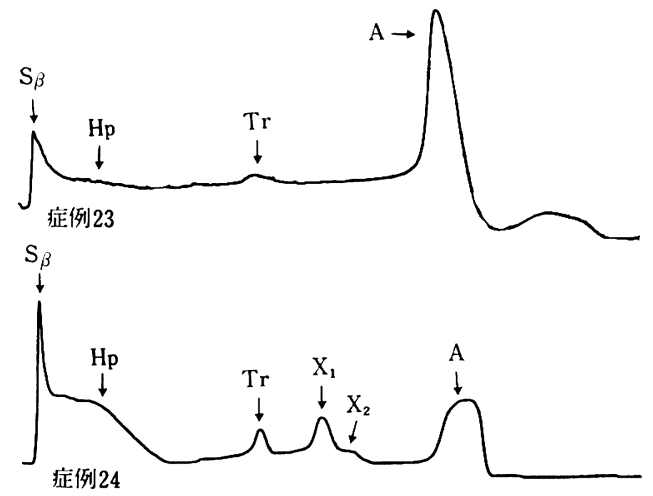

図 8 エナメル上皮腫内容液のディスク電気泳動像
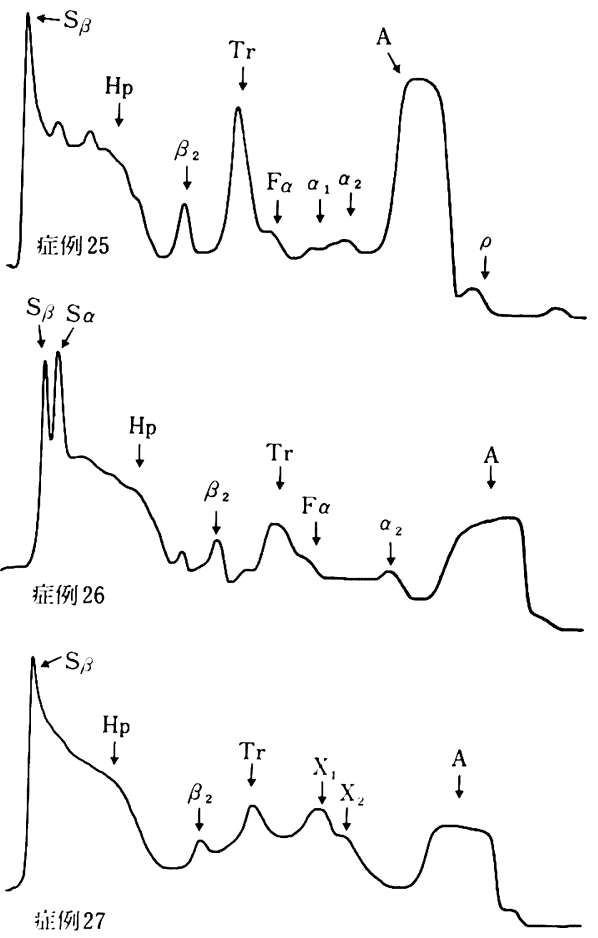

図 9 歌整胞内容液のディスク電気涾㨽像

できる.

型胞内容液の蛋白成分をディスク電気泳動的に分画し た結果を，図2〜9にデンシトグラムで示した．血清の泳 動像に近い所見を示したものとしては，歯根擎胞の 3 例， 沪胞性歯裂胞の 1 例, 術後性頓部琵胞の 1 例㧍よび診断 の確定されなかった顎雔胞の 1 例の合計 6 例であったが, 他の21例は血清とは異なる特異な泳動像を示した.

なお，缹胞内容液において，Trと albumin の間に泳 動する 2 つ画分が分離されることがあった.このらち， 速く泳動する画分の易動度は $\alpha_{1}$ にほぼ一致するが，通 常この 2 つ画分は相伴って出現するので, 遅く泳動す る画分を $X_{1}$, 速く泳動する画分を $X_{2}$ と呼んで区別し た。

\section{崡根政胞}

図 2 に示したように，8 例中の 3 例（症例 1，4，5） が血清にきわめて近い泳咀像を示した，他の症例も比較 的血清に近いが， 3 例（症例 $3 ， 6 ， 7 ） に \alpha_{1}, \alpha_{2}$ の付 近に增加する 2 つの成分 $\left(\mathrm{X}_{1}, \mathrm{X}_{2}\right)$ が分離された.

症例 8 では， $\mathrm{S}_{\beta}$ 扣よび $\mathrm{S}_{\alpha}$ の欠如がみとめられた.

症例 2 は，被検例中最も特異な泳動像を示した。すな わち, $A$ 以外の成分が著るしく減少して拈り， $S_{\beta}$ 拈よび Tr の他はあきらかな分離がなされなかった.

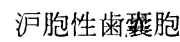


4 例中の 1 例（症例12）は血清に近い泳動像を示した が， $\alpha_{2}$ は增加し Hp は減少していた（図3）.

Hp の減少がみとめられたのは，この1例のみで，他 の3 例では逆に増加して打り，とくに，その中の 2 例 （症例 9，10）ではA濃度が減少しているので，Hpの対 albumin 相対濃度は正常血清の場合よりあきらかに高く なっていた.

また $\alpha_{2}$ の增加も他の症例ではみとめられず，むしろ 减少する傾向に方り，症例 9 尔よび11では $\alpha_{1}, \alpha_{2}$ 拈よび 到が peak としてみとめられ程度にまで低下していた。

症例10に括いては，Tr の前後に泳動する画分の著明 な増加がみとめられ，Trとともに大きな mono-peak が 形成された。

\section{術後性頓部襄胞}

6 例中の 1 例（症例13）は，血清にきわめて類似した 泳動像を示したが，他の 5 例では，A 拉よび $S_{\beta}$ を除く 他の蛋白成分の著明な减少がみとめられた. とくに $\alpha_{1}$, $\alpha_{2}$ が火如し，低下した Tr の peak からAの peak に 至るまで平担なデンシトグラムが得られた（図 4).

$\mathrm{S}_{\beta}$ は， 6 例中 4 例飞执いて，A ととも滈濃度にみ とめられ，対 albumin 相対濃度は血清の場合に近いが，

2 例（症例 $17 ， 18 ） 飞 お い て ， \mathrm{Hp}$ ととあ著明に減少 しており，症例18では peak としてみとめられ始度に まで減少していた。

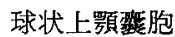

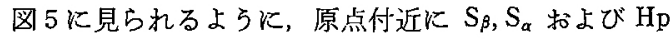
い一部からなる mono-peak が形成された後，Aの peak まで平担な，きわめて特異なデンシトグラムが得られた。

\section{鼻歯槽整胞}

血清に比較的類似した泳動像を示したが，A 拈よび Tr の間泳動する 2 つの画分 $\left(\mathrm{X}_{1}, \mathrm{X}_{2}\right)$ の対 albınin 濃度 が著明に增加して和り，一方 $\operatorname{Tr}$ の浱度が低下していた (図 6).

\section{ガマ尰}

$\operatorname{Tr}$ の対 albumin 濃度があきらかに娍少しており， $S_{\beta}$ を除く他の蛋白成分についても著明な減少がみとめ られた．各画分の分離はあきらかではなく，デンシトグ ラムに和いて $\mathrm{S}_{\beta}, \mathrm{Hp}, \mathrm{Tr}$ 特よびAの peak が識別され K: (図 7 ).

\section{エナメル上攴腫}

I例（症例23）は，Aより遅く泳動するすべての成分 が著明に減少，むしくは消失した泳動像を示した．本症 例において，Aの減少はみとめられず，また prealbumin 画分 $(\rho)$ の つがあきらか增加していた.

他の 1 例では，A， Tr, Hp 画分のあきらかな減少がみ とめられた。 また， $\mathrm{X}_{1}$ の出現がみとめられた（図8）.

\section{顎巽胞}

図9に示したよらに，検索した 3 例中の 1 例(症例25) は，血清にきわめて類似した泳毁像を示し，他の 2 例も

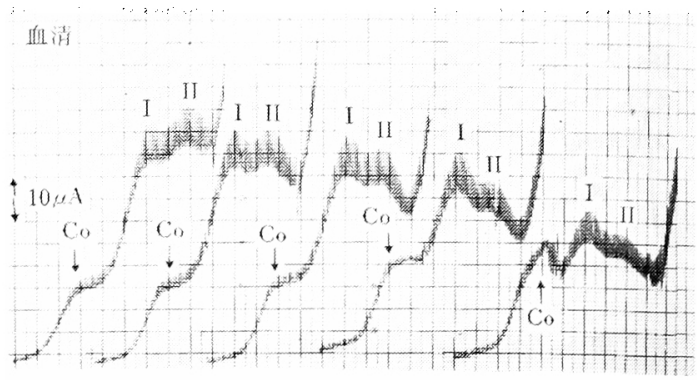

図 10 血清の蛋白波拈よび交刃効果

Co：コバルr波，I：第1波，II：第 2 波

左から順に，電解液中の血清濃度が倍数稀勫されている.

比較的血清に近い泳動像を示した。

症例26ではTr和よびAが減少していたはか， $\alpha_{2} か ゙$ 分 離されなかった。

症例27では症例26之同様に, $\mathrm{Tr}$ 和よび A 減少がみ とめられたが， $X_{1}$ および $X_{2}$ のあきらかな出現がみとめ
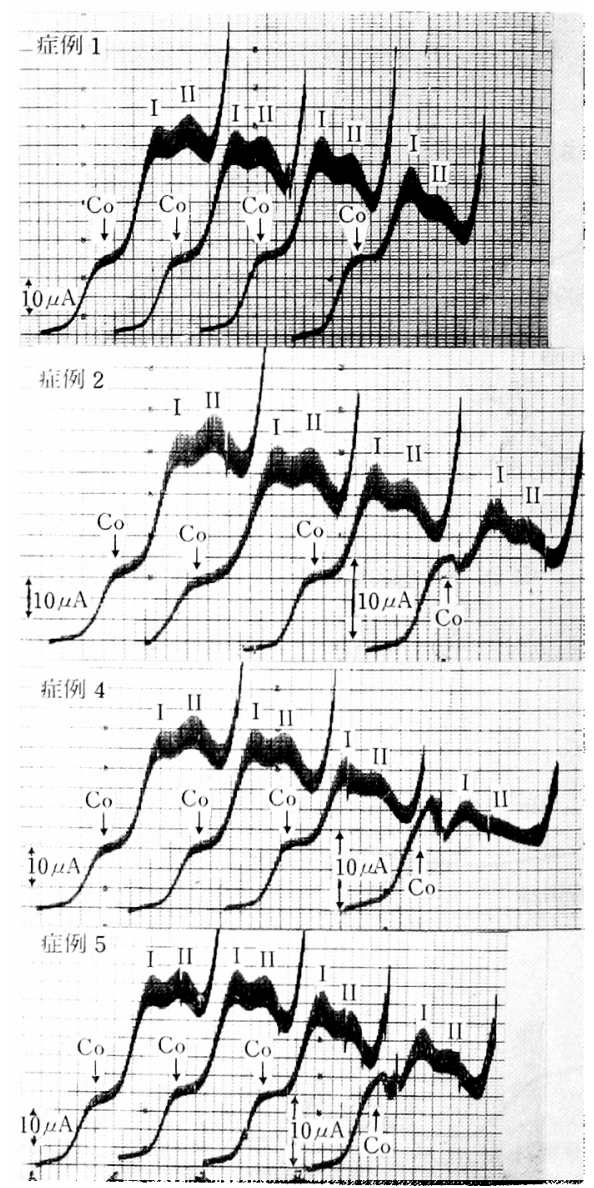

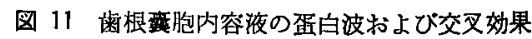




\section{られた。}

\section{3. 蛋白波および交叉効果}

枆胞内容夜の特質をあきらかにするための一方法とし て，垔胞内容液の蛋白波について検索した。 まず，塩化 コバルトを含さ塩化アンモンーアンモニア緩衝液中にお ける，いわゆる Brdička の蛋白波执よび交攴効果につ いて得られた結果をのべる.

図10に示したよらに，血清はー1. 1 volt 付近のコバル ト波にひき続き，一1.4 および -1.6 volt 付近に，蛋白

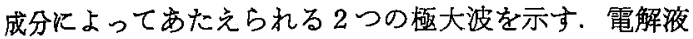
中に打ける血清の濃度が高い場合には，コン゙ルト波にひ き続いてあらわれる第 1 波よりも，第 2 波の波高の方が 高い(Brdička の蛋白波). しかし，血清の電解液中の濃 度を下け゚るにしたがい，第 2 波は第 1 波よりる急速に波 高を減じて，遂には第 1 波と第 2 波の波高が逆転する.

すなわち，蛋白波の交攴効果がみとめられる，今回の実

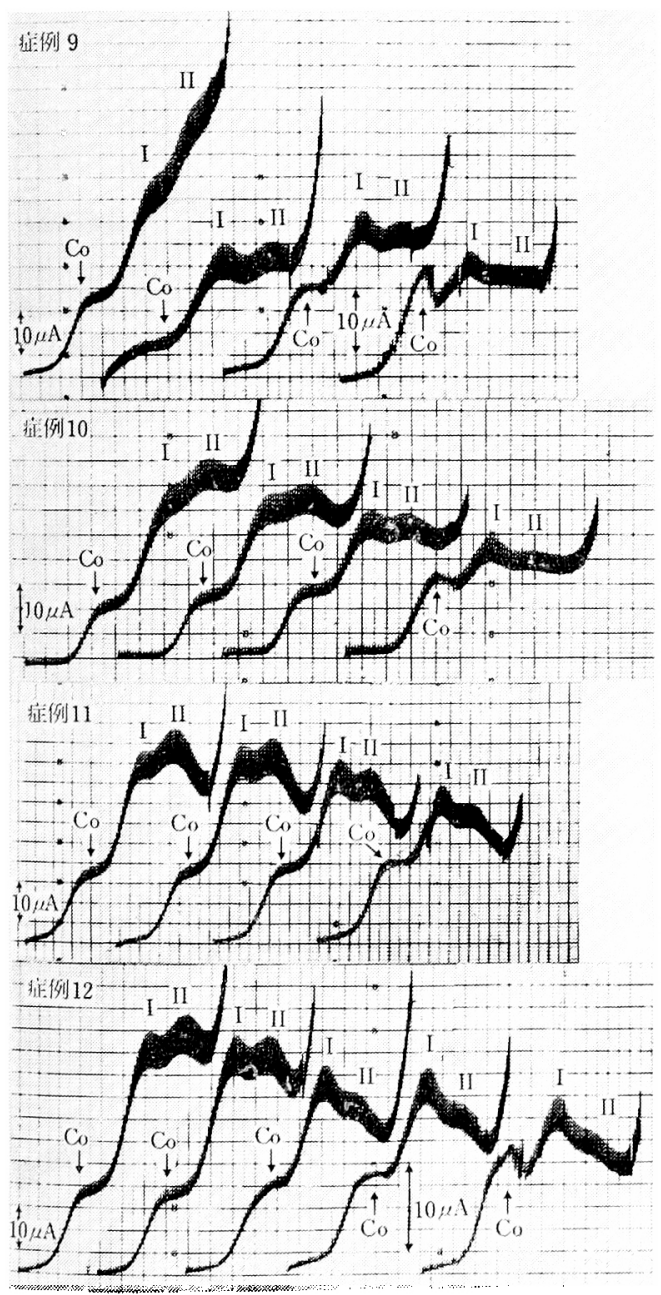

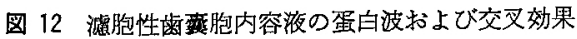

験条件に扣ける血清の交攴点は，蛋白濃度にして3.2(X 10-2\%)であった。

幽根裂胞

図11に代表例を示した，全例（8例）において，血清

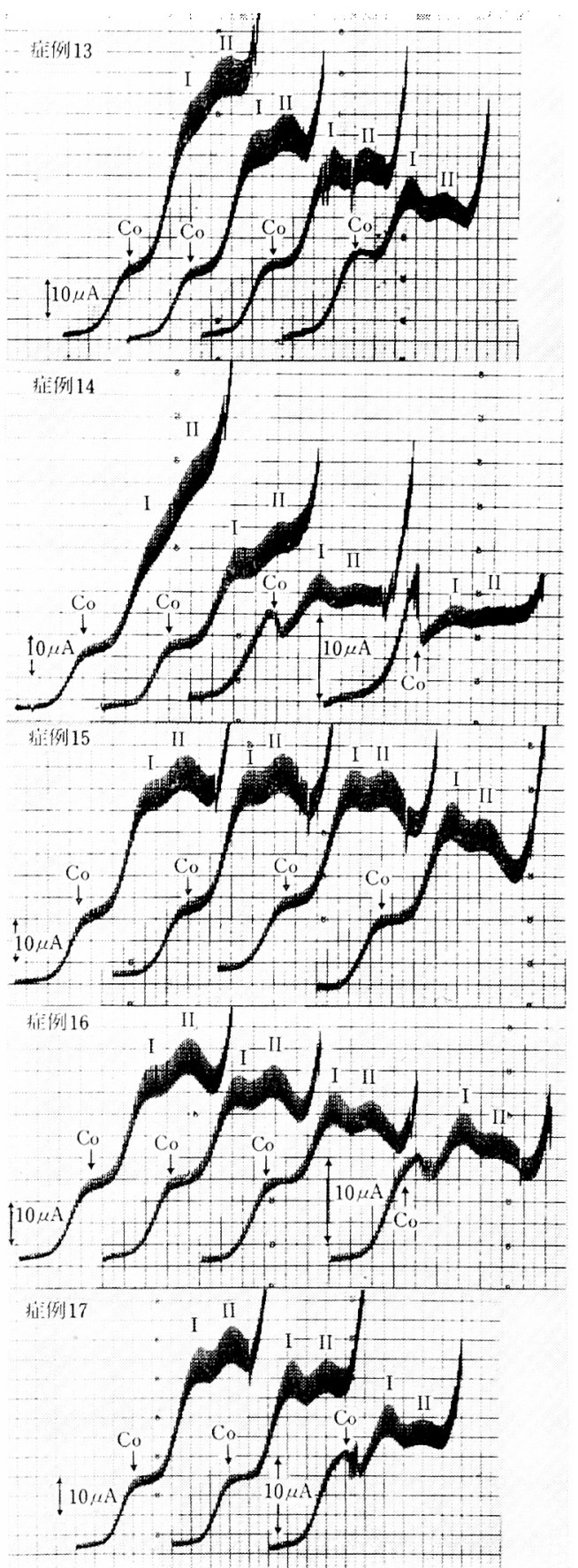

図 13 術後性頓部蔪胞内容液の蛋白波および交文効果 
にきわめて類似した蛋白波扣よび交文効果がみとめられ

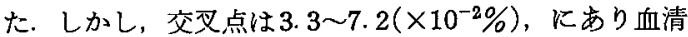
にくらべて高い值を示した.

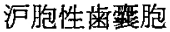

図12kみられるよ5に，4例中の 2 例（症例 9，10） に拈いて血清とはあきらかに異なる蛋白波が示された。 すなわち，第 2 波に対する第 1 波の比が小さく，第 2 波 の極小 (minimum) がみとめられない特異なポーラログ

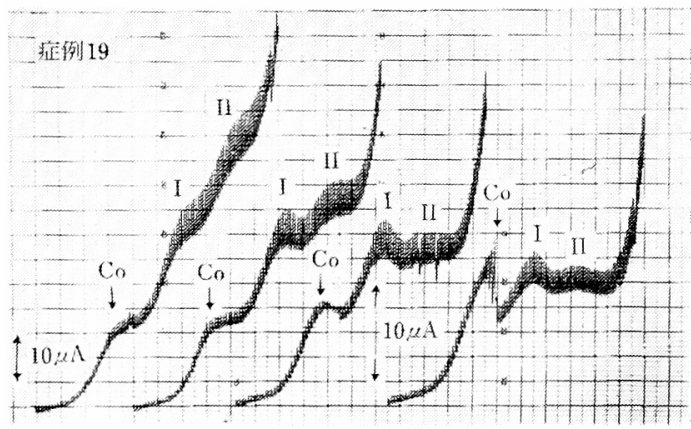

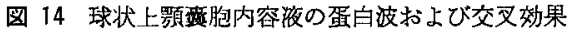

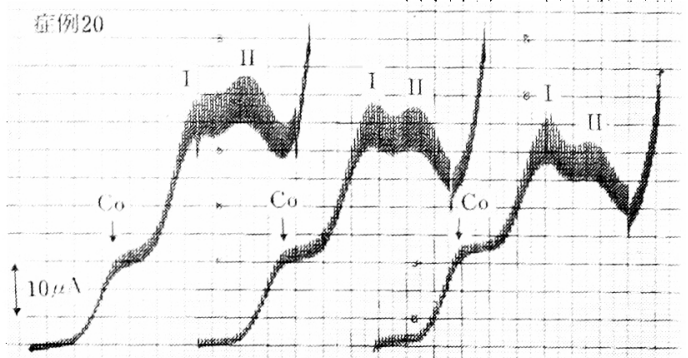

図 15 歯槽栾胞内容液の蛋白波および交叉効果

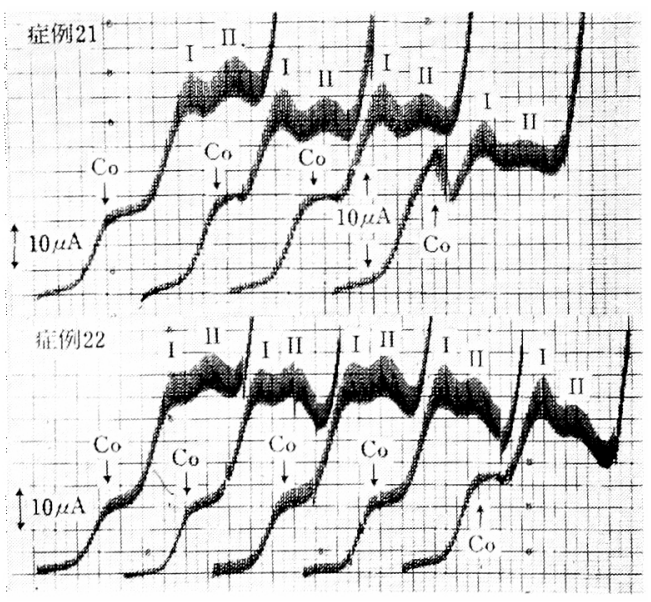

因 16 ガマ瘇内容液の蛋白波および交叉效果
ラムが得られた。他の 2 例（症例11，12）は，血清に類 似した蛋白波を示した。しかし，症例12は交要効果のあ らわれ方に执いて血清と暴なり，交文点は6.8(×10-2\%) で４例中最も高い值を示した。

術後珄頓部霜胞

検索された 5 例中 2 例（症例13，14）が血清とは異な る特異な蛋白波を示した（図 13）。この5ち1例（症例 14）は沪胞性䨑整胞の 1 例（症例 9）にきわめて類似し

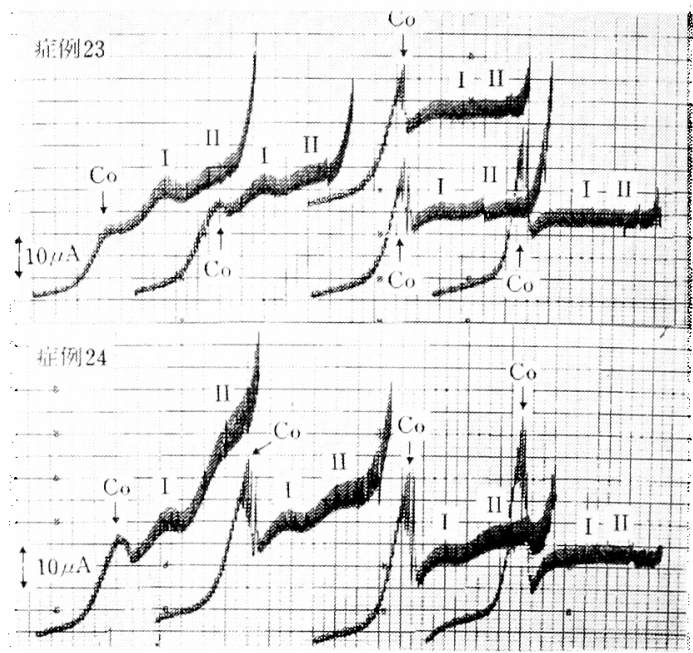

図 17 エナメル上敒腫内容液の蛋白波および交叉効果
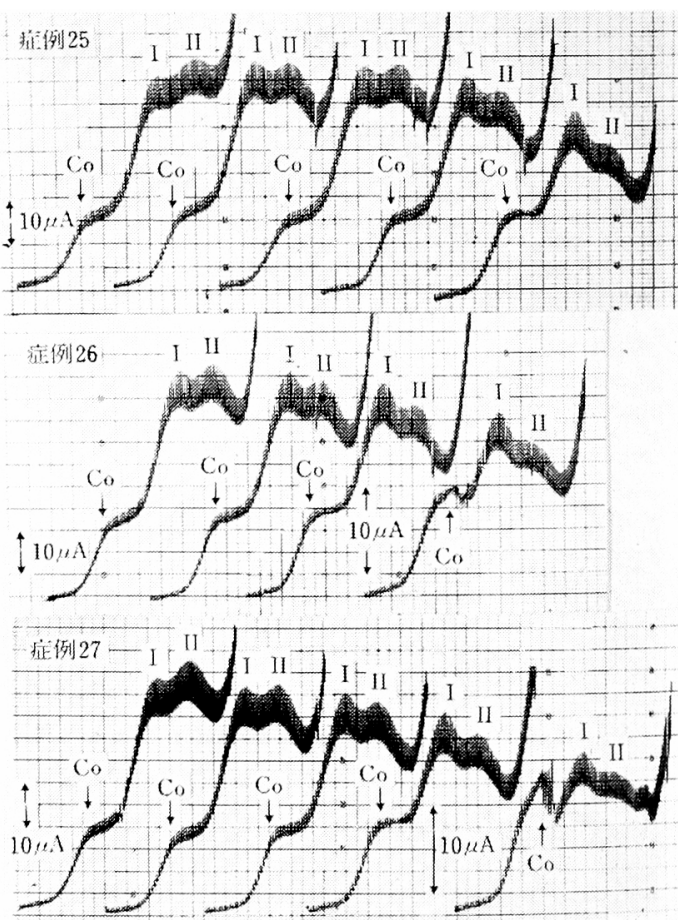

図 18 䫓高胞内容夜の蛋白波および交叉効果 

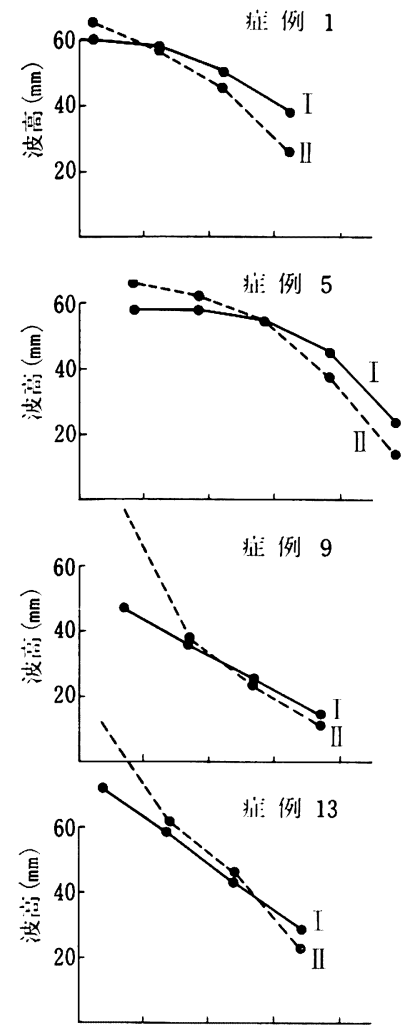

拉: 例 17

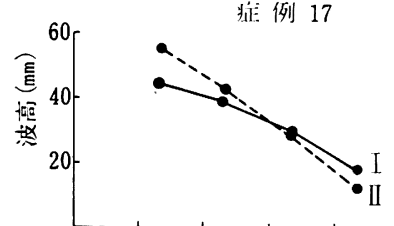

註例 21
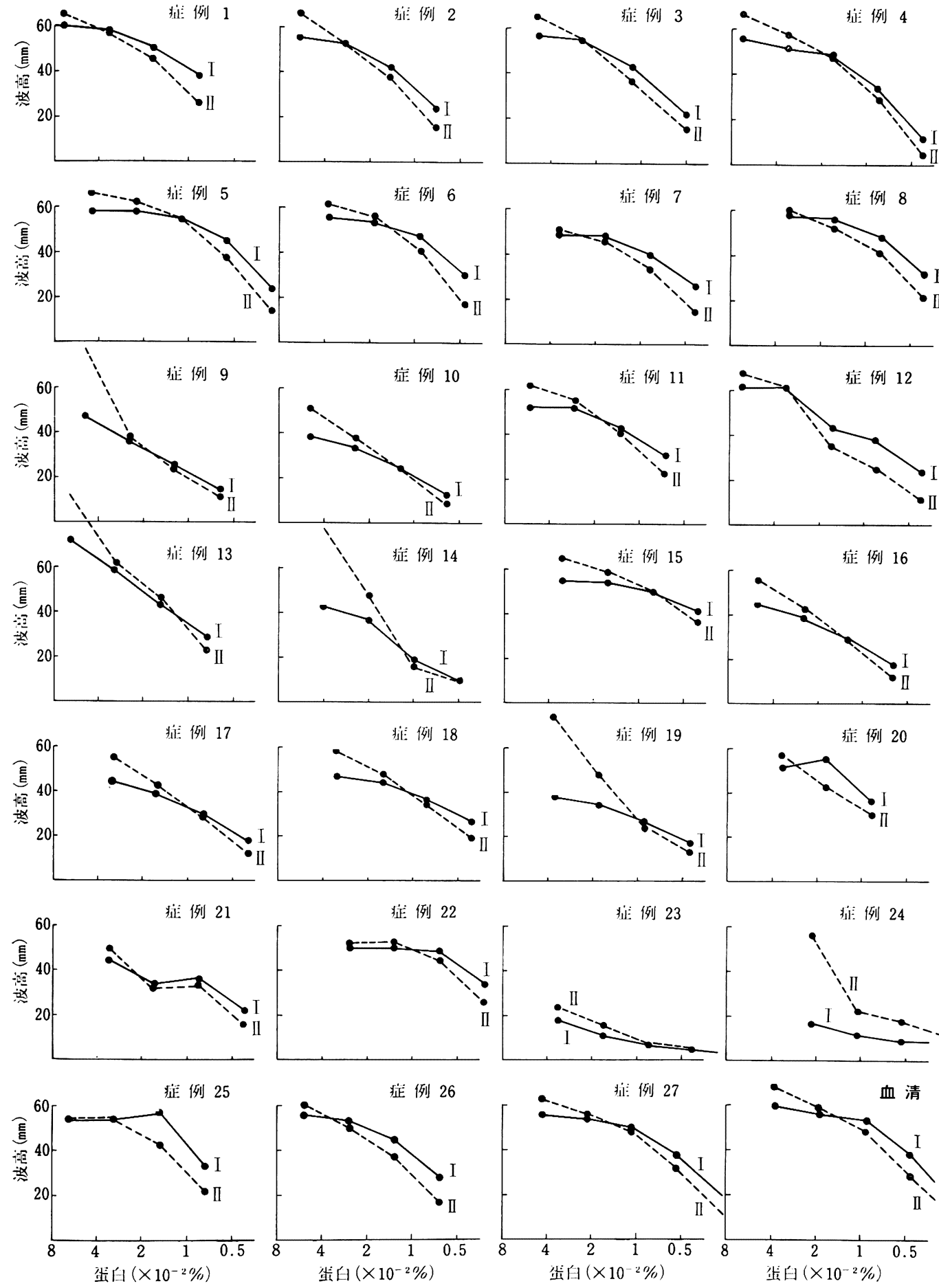

隹: 例 7
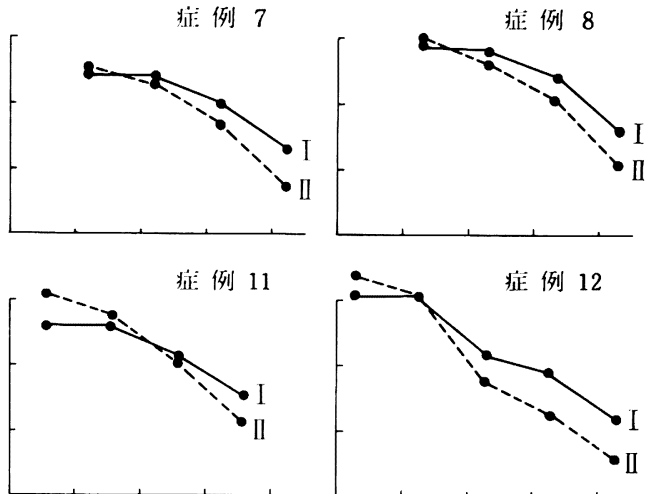

症例 16
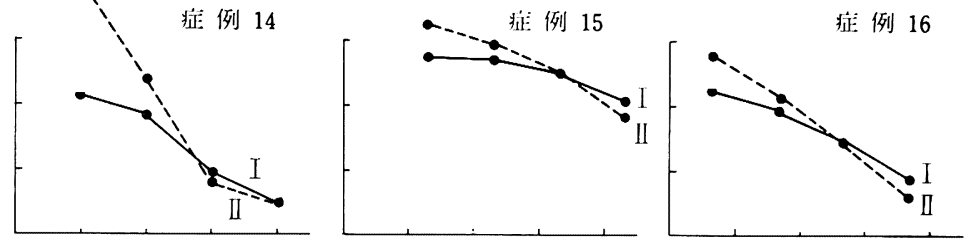

註: 例 18

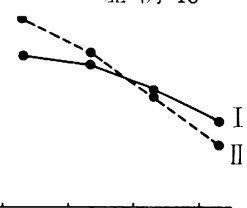

症例 22

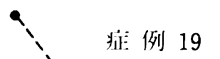

症例 20

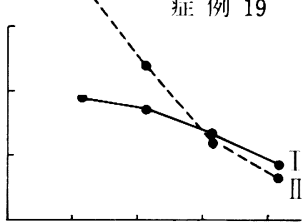

证: 例 23

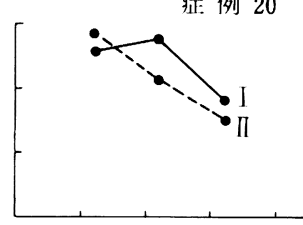

将: 例 24
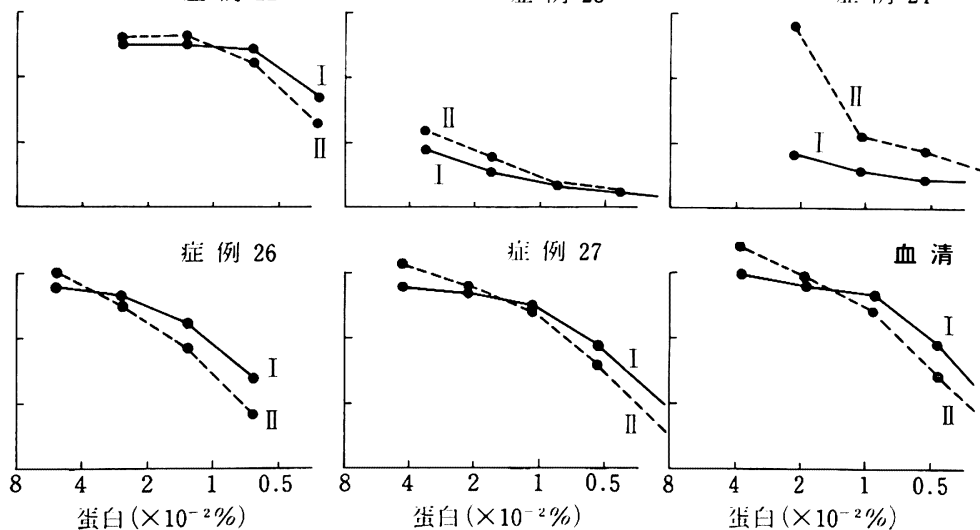

血 清

図 19 各種胞内容液の交叉効果

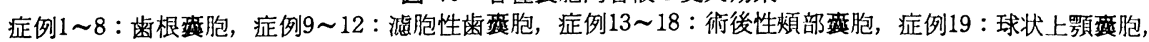

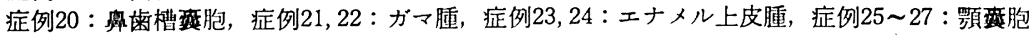

I : 第 1 波, II : 第 2 波 


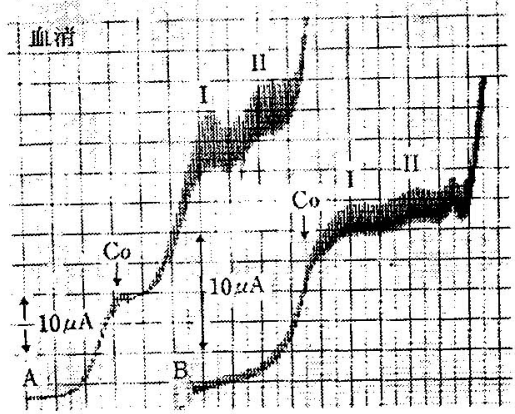

図 20 血清の第一反応捻よび溜液反応 $\mathrm{A}: \mathrm{KOH}$ で変性した血清の蛋白波（第一反応） $\mathrm{B}: \mathrm{KOH}$ 变性後, スルホサリチル酸で除蛋白し た滤液の接触嗃元波（濾液反応）Co：コバルト 波, I：第 1 波, II：第 2 波

ていたが，他の 1 例（症例13）は第 2 波に minimumが みられる点で特異であった.

5 例すべてに交叉効果がみとめられた，交叉点は 1.6

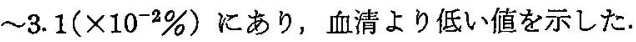

\section{球状上䫇軎胞}

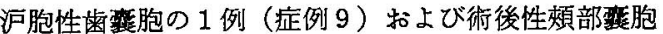
の1例（症例14）と同型の蛋白波出よび交文効果を示し た，交父点は $2.1\left(\times 10^{-2} \%\right)$ で，症例 9 およ゙14よりる 低い（図14）.

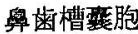

血清に類似した蛋白波を示したが，電解液中の窖胞内 容液の濃度を次第に減じると，第 1 波の波高が一度上昇 してから下降し，特暴な交文效果を示した. 交叉点は 5. 8(×10-2\%) であった（图15）.

\section{ガマ尰}

血清に類似した蛋白波を示したが，蛋白濃度の娍少に ともなら波高の低下が滑らかでなく，特異な交攴効果を 示した. 交丑点は症例21では $4.1\left(\times 10^{-2} \%\right)$ と高く，症 例22では $2.2\left(\times 10^{-2} \%\right)$ と低い值であった（図16）.

エナメル上皮腫

図17にみられるよらに，第 1 波に対して第 2 波の立ち

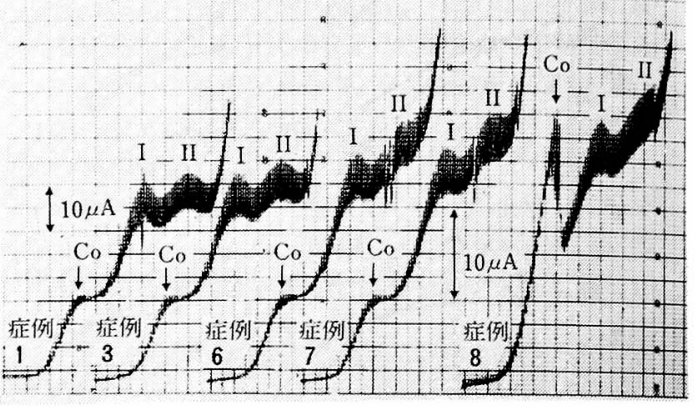

図 21 齿根弯胞内容液の第一反応

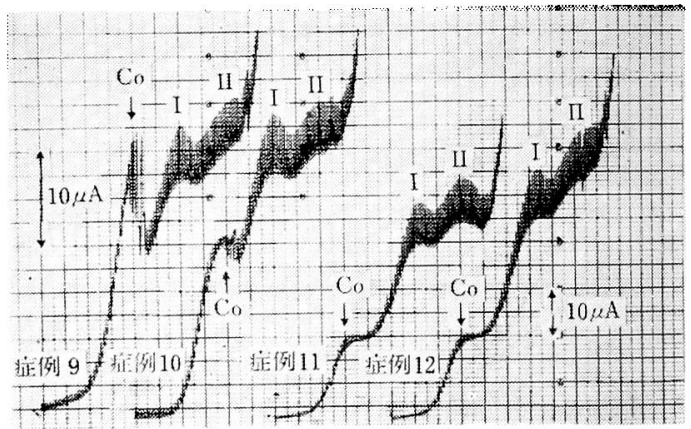

图 22 源胞性要胞内容夜の第一反応

上りが強く，血清とはあきらかに異なる蛋白波を示した。 検索された 2 例のいずれる，第 1 波に minimum がみと められたが，このような特徴をすった蛋白波は，他の症 例からは得られなかった。また，2例と交丑効果を示 さなかった。

\section{颚襄胞}

検索された 3 例は，いずれも血清に類似した蛋白波括

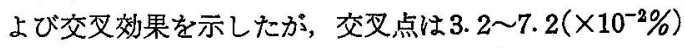
で高く，歯根霍胞の值に近かった（図18）.

全症例の交叉効果を図19にぬとめた。同困においては， 同一種類に属する慗胞の場合でも，症例ごとに多様に変 化しているが，集胞の種類別による特徴すみることがで きる。

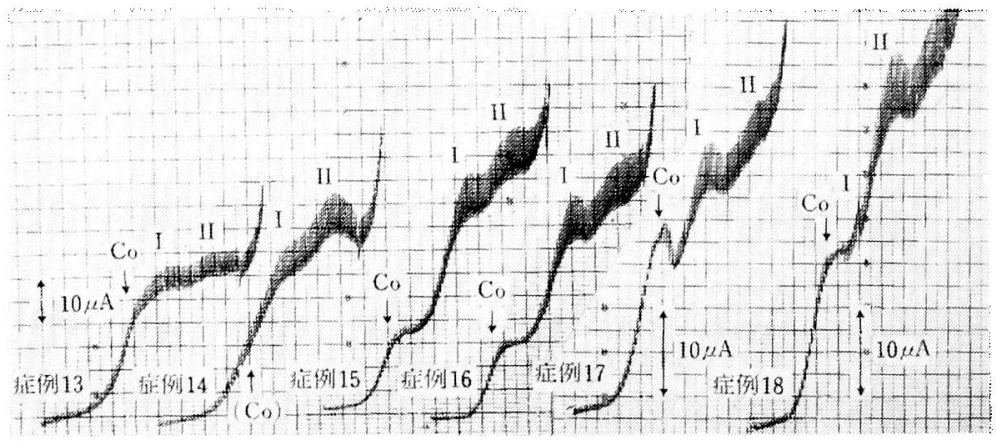

図 23 琎後性煩部醖胞内容液の第一区応 


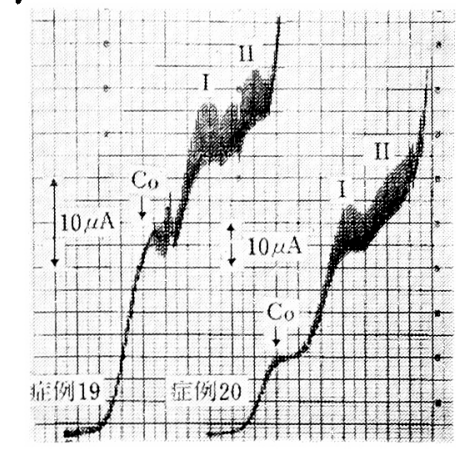

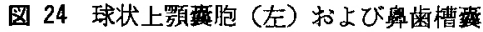
胞内容液 (右) の第一反応

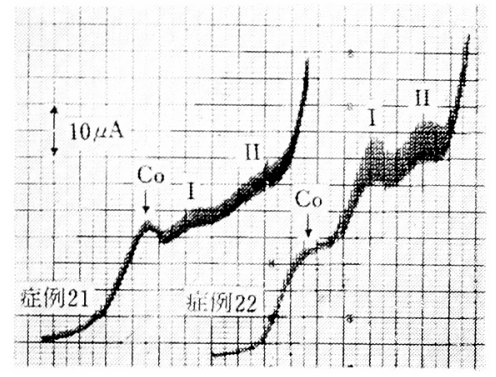

図 25 ガマ腫内容液の第一反応

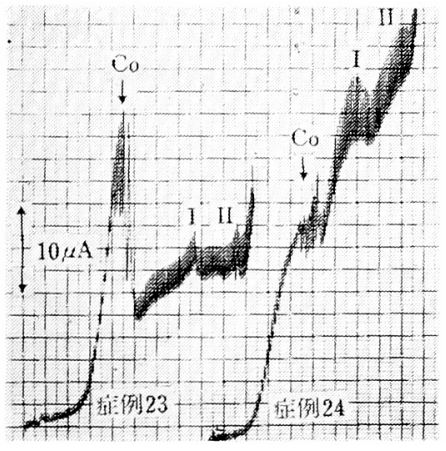

図 26 エナメル上皮腫内容液の第一反応

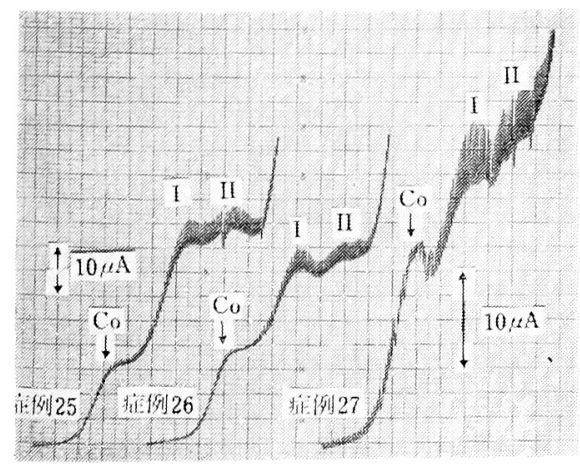

図 27 影鞍胞内容旅の第一区応
4. 第一反応（アルカリ変性反応）

血清および整胞内容液に KOH を加えて蛋白成分をつ ルカリ変性せしめたのち，蛋白波の第 2 波の波高を測定 して比較観察した.

图 20-A のポーラログラムは正常血清の第一反応を示 したものである．第 2 波の波高は $53 \mathrm{~mm}$ であった．

各種巽胞内容液の第一反応上して得られたポーラログ ラムを, 図21〜27に示した。

\section{齿根整胞}

8 例のうち， 5 例は 44 $51 \mathrm{~mm}$ で血清よりわずかに低 い値を示した．しかし，2 例に打いて66拈よび70 $\mathrm{mm}$ と 血清より高く、1 例は $27 \mathrm{~mm}$ ときわめて低い值を示した (図21).

\section{沪胞性歯変胞}

4 例のらち，さきの未変性試料において，血清とは異 なる特異な蛋白波を示した 2 例の波高が 24 和よび $26 \mathrm{~mm}$ ときわめて低く，血清に類似した蛋白波を示した 2 例は 56扣よび75 mmで血清よりる高い值が得られた（図22）.

\section{術後性煩部嫼胞}

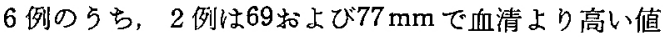
を示し， 3 例においては20 50 $\mathrm{mm}$ と低い値で，1 例は $53 \mathrm{~mm}$ で血清と同じ值であった（図 23），未资性試料に 特いて，血清とは異なる特異な蛋白波を示した 2 例（症 例13，14；図13）についてみると，1例が20 $\mathrm{mm}$ できわ めて低い値を示したが，他の 1 例は $53 \mathrm{~mm} て ゙ ，$ 血清と同 じ值であった．これに対して，血清に類似した蛋白波を 示した症例の一つは, $31 \mathrm{~mm}$ 之低い值を示した.

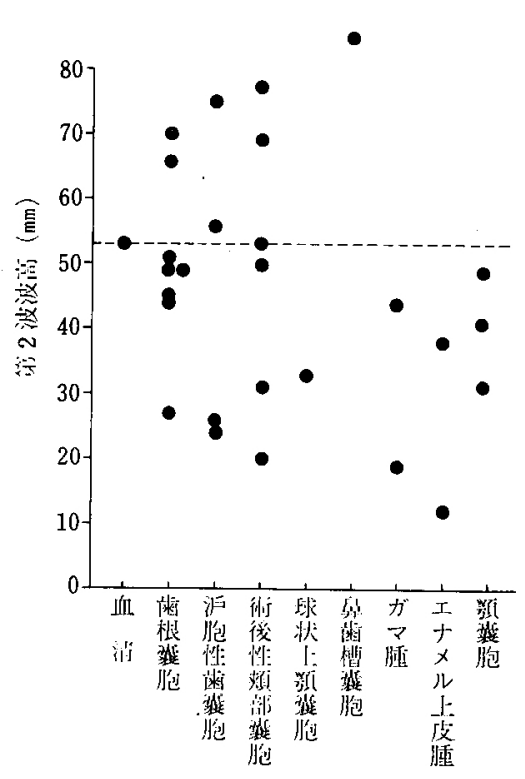

図 28 近清および胞内容液の第一反応 


\section{球状上䫫栾胞}

$33 \mathrm{~mm}$ で血清よりはるかに低い値を示した（図24,左）

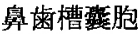

$85 \mathrm{~mm}$ で血清より高い值であった（図24,右）

ガマ腫

2 例に括いて，19および44 mmで，いずれも血清より
みとめられなかった（図31）。

球状上罰鸾胞

$11 \mathrm{~mm}$ で血清より低い値を示した（図32,左）

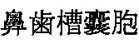

$7 \mathrm{~mm}$ で血清よりはるかに低い値を示し，崡根蓗胞の 1 例（症例 3 ）とともに全症例中，最低值であった（図 低い值を示した（図25）。

\section{エナメル上皮腫}

2 例に括いて，12および38 mmで， いずれも血清より低い值であった. この 2 例は, 鼠歯槽垔胞の 1 例とと 子に，未変性試料に和いて，非血清 型の特異な蛋白波を示したものであ る. 結局, 非血清型の特異な蛋白波 を示した症例の大部分 ( 7 例中 6 例) が第一反応に颃いて，第 2 波波高の 著明な減少を示した（図26）.

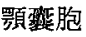

3 例のうち， 1 例が $59 \mathrm{~mm}$ で血清 より高い值を，2例が 41 および 31 $\mathrm{mm}$ と低い值を示した（図27）。

慗胞の種類別に，第 2 波波高の計 测値をまとめて，図28に示した。

5. 滤液反㤁

血清怙よび怔胞内容液について， $\mathrm{KOH}$ 変性後スルホサリチル酸（SS A) で除蛋白した沪液の，コボルト を含む程化アンモンーアンモニア緩 衝夜中に扣ける接触還元波を記録し， とくに，その第 2 波波高の挙動を㭘 索した.

正常血清の沪液反応によるポーラ ログラムは図20-Bに示したように， コパルト波が強く抑制されている。 第 1 波执よび第 2 波の波高は低く， 同図に颃いて，第 2 波波高は $17 \mathrm{~mm}$ であった.

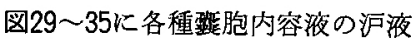

反応として得られたポーラログラムを示した。

相根聚胞

8 例の第 2 波波高は 7 13 mm でよくまとまった値を 示した．血清の $17 \mathrm{~mm}$ にくらべて低い值であった（図 29).

\section{汇胞性歯変胞}

4 例の5ち， 3 例が 9 15 mm で血清より低く，1例 が29 mm と高い值を示した（図30）。

\section{術後性煩部整胞}

全症例において血清より高い值で，とくに，3例は42 〜 $56 \mathrm{~mm}$ と高く，このような高い併を示した症例は他に

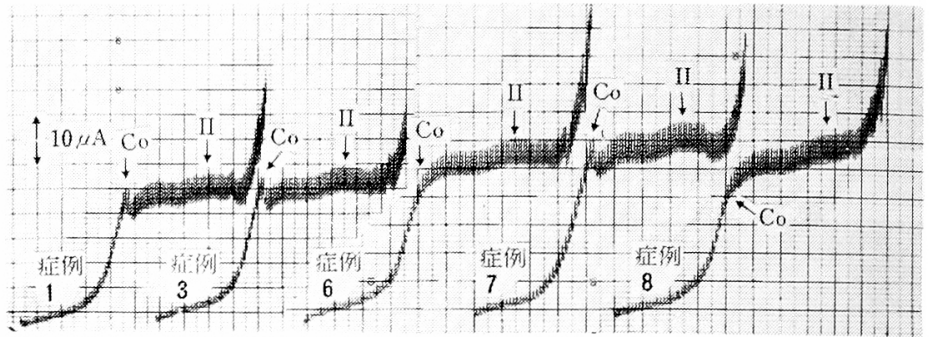

图 29 歯㮛葓胞内容液の澽液区応

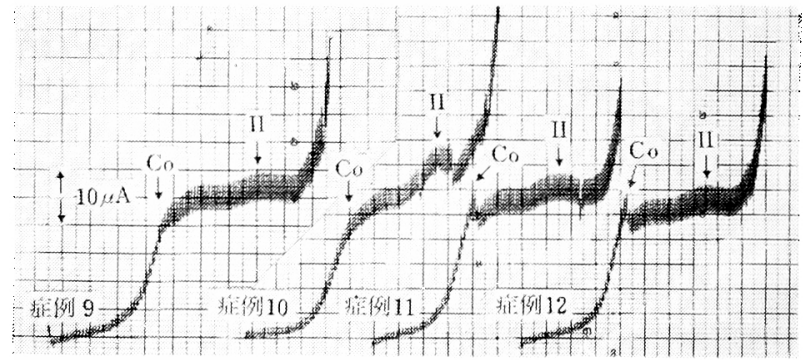

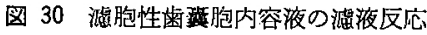

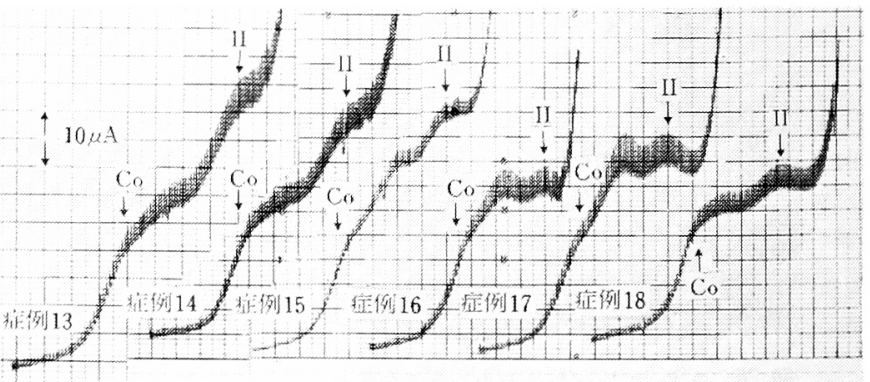

図 31 街後性煩部萃胞内容液の滤液反店

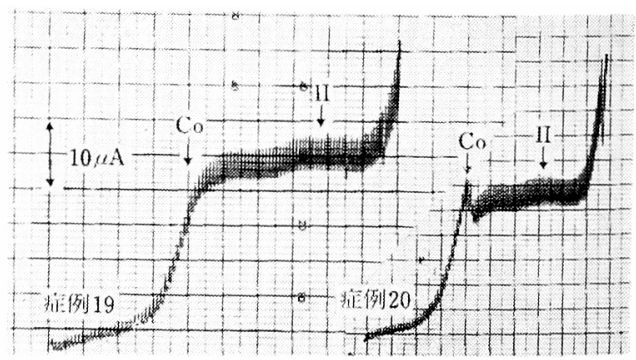

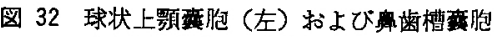
内容液（有）の海液反它 


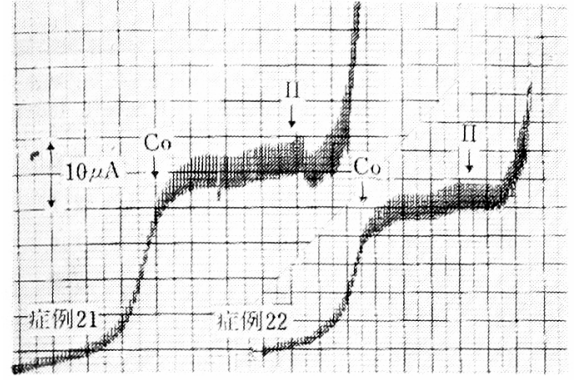

図 33 ガマ腫内容液の源液反応

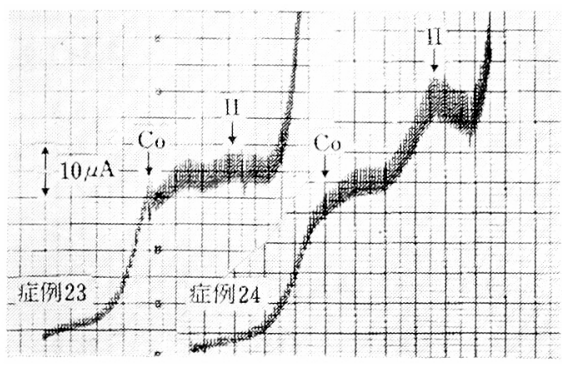

図 34 エナメル上皮腫内容液の滤滩反応

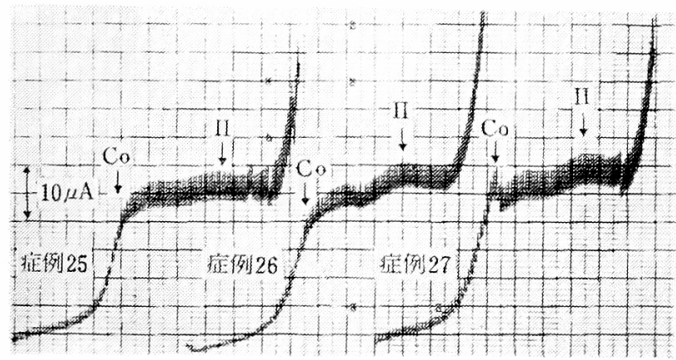

图 35 頻挛胞内容液の濾液反応

32 , 右).

\section{ガマ尰}

2 例において，10および $16 \mathrm{~mm}$ で，血清にきわめて近 い值か，低い顛を示した（図33）.

エナメル上皮腫

1 例は $40 \mathrm{~mm}$ で, 術後性煩部缼胞に和いてみられたよ らな高い值を示し，他の 1 例は $12 \mathrm{~mm}$ で，血清より低い 値を示した（図34）.

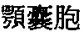

3 例のちち，2 例に和いて，9１1 mm と血清よりる 低い值を示し，他の 1 例は $16 \mathrm{~mm}$ で血清にきわめて近い 值であった（図35）。

結局，沪液反応において，血清より高い值を示した症 例は少なく，27例のらち 4 例であった.この 4 例中の 3 例が術後性頓部翼胞であり，他の 1 例はエナメル上皮腫 であった。

\section{6. protein index}

上記の第一反応拈よび沪液反応に扎いて得られた，そ

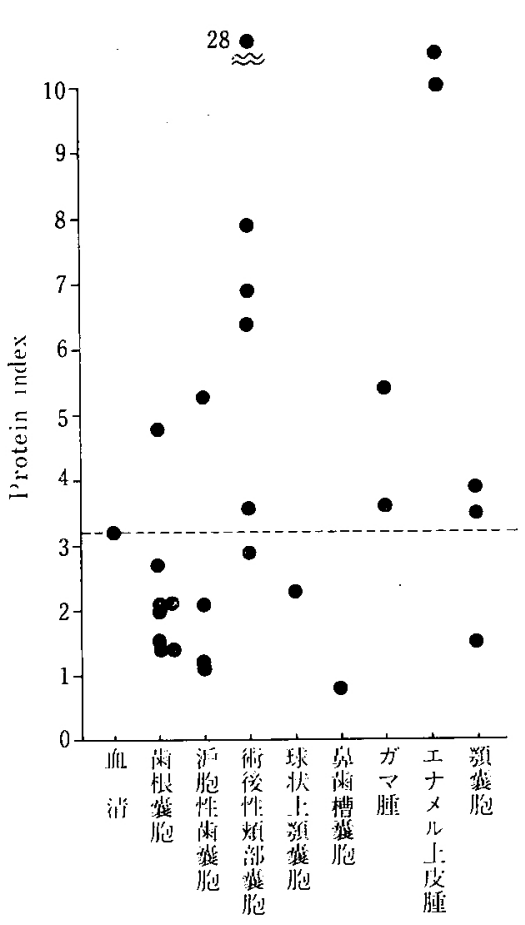

図 36 血清および亦胞内容液の Protein index

れぞれの第 2 波波高の計測值を，研究方法の項で还べた 算式にあてはめて血清扣よび㨟胞内容液の protein indexを求めた。得られた結果を図36に示した。

正常血清の protein index 3.2 に対して，歯根辈胞内 容腋に持ける 4.8 と，とくに高かった 1 例をのぞけば，

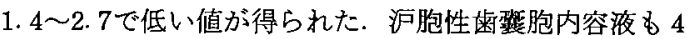

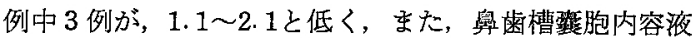
においても，0.8ときわめて低い值を示した。

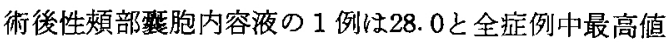
を示し，他の 4 例む3.6〜7.9 と高い值を示した. エナ.

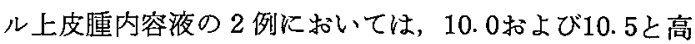
い値を示した.

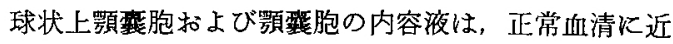
似の protein index を示した。

以上のポーラログラフ的研究結果を，表 2 にをとめて 示した。

7. 水分, 有機成分, 灰分, 蛋白, 総ステロールおよ びシアル酸

血清括よび霍胞内容液の水分，有機成分，灰分，蛋白， 総ステロールおよびシフル酸を定量して得られた成結を 表 3 に示した.

水分量

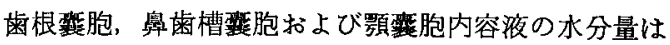

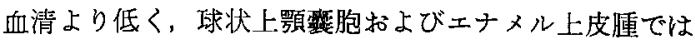


表 2 伹清および胞内容液のポラドグラフ的査索結果

\begin{tabular}{|c|c|c|c|c|c|c|}
\hline 鸾胞の種類 & $\begin{array}{l}\text { 症例 } \\
\text { 番号 }\end{array}$ & $\begin{array}{l}\text { 蛋白波の } \\
\text { 形 状 }\end{array}$ & $\begin{array}{l}\text { 交 叉 点 } \\
\left(\text { 蛋白 } \times 10^{-2} \%\right)\end{array}$ & 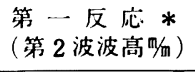 & $\begin{array}{l}\text { 滤液 反応 } * * * \\
(\text { 第 } 2 \text { 波波高 } \mathrm{m} / \mathrm{m})\end{array}$ & $\begin{array}{r}* * * \\
\text { Protein Index }\end{array}$ \\
\hline \multirow{8}{*}{ 歯 根 森 胞 } & 1 & 租 清 型! & 7.2 & 45 & 9 & 2.0 \\
\hline & 2 & 血 清 型 & 5.8 & 49 & 10 & 2.1 \\
\hline & 3 & 血 清 型 & 4.5 & 49 & 7 & 1.4 \\
\hline & 4 & 血 清 型! & 4.2 & 51 & 11 & 2.2 \\
\hline & 5 & 组 清 型 & 2.5 & 44 & 12 & 2.7 \\
\hline & 6 & 血 清 型! & 3.3 & 66 & 10 & 1.5 \\
\hline & 7 & 侐 清 型! & 5.6 & 70 & 10 & 1.4 \\
\hline & 8 & 拈 清 型! & 5.2 & 27 & 13 & 4.8 \\
\hline \multicolumn{2}{|c|}{ 平均土標辈偏差 } & & $4.8 \pm 1.39$ & $50.1 \pm 12.5$ & $10.3 \pm 1.7$ & $2.3 \pm 1.0$ \\
\hline \multirow{4}{*}{ 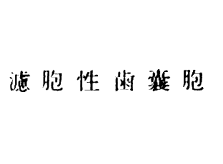 } & 9 & 非血清型 & 3.7 & 24 & 15 & 6.3 \\
\hline & 10 & 非 血清型! & 2.8 & 26 & 29 & 1.1 \\
\hline & 11 & 血 清 型! & 3.8 & 56 & 12 & 2.1 \\
\hline & 12 & 桖 清 型! & 6.8 & 75 & 9 & 1.2 \\
\hline \multicolumn{2}{|c|}{ 平均土標淮偏羑 } & & $4.3 \pm 1.5$ & $45.3 \pm 21.3$ & $16.3 \pm 7.7$ & $2.7 \pm 2.1$ \\
\hline \multirow{6}{*}{ 術後性: 頬部輩胞 } & 13 & 非血消型! & 2.7 & 20 & 56 & 28.0 \\
\hline & 14 & 非血消型! & 2.6 & 53 & 42 & 7.9 \\
\hline & 15 & 稆 㴯 型! & 1.6 & 77 & 53 & 6.9 \\
\hline & 16 & 血 清 型! & 3.1 & 69 & 20 & 2.9 \\
\hline & 17 & 血 清 型! & 1.9 & 31 & 23 & 7.4 \\
\hline & 18 & 血＼cjkstart清 型! & 2.3 & 50 & 18 & 3.6 \\
\hline \multicolumn{2}{|c|}{ 平均土標準偏差 } & & $2.4 \pm 0.5$ & $50.0 \pm 19.9$ & $35.3 \pm 15.7$ & $9.5 \pm \imath .5$ \\
\hline 球状上額留胞 & 19 & 非血清型! & 2.1 & 33 & 11 & 3.3 \\
\hline 息 粎 槽 胞 & 20 & 组 清 型! & 5.8 & 85 & 7 & 0.8 \\
\hline \multirow{2}{*}{ ガ $\quad$ 腫 } & 21 & Ifll 清 悡! & 4.1 & 19 & 10 & 5.3 \\
\hline & 22 & 稆 清 型! & 2.2 & 44 & 16 & 3.6 \\
\hline \multirow{2}{*}{ エナメル上皮胛 } & 23 & 非 血消型! & - & 12 & 12 & 10.0 \\
\hline & 24 & 非血清型 & - & 38 & 40 & 10.5 \\
\hline \multirow{3}{*}{ 頻翟胞 } & 25 & 血 清 型! & 6.2 & 59 & 9 & 1.5 \\
\hline & 26 & 血 清 型! & 7.2 & 41 & 16 & 3.9 \\
\hline & 27 & Ifll 清 犁! & 3.2 & 31 & 11 & 3.5 \\
\hline \multicolumn{2}{|c|}{ 平均土標淮偏差 } & & $5.5 \pm 1.7$ & $43.7 \pm 11.6$ & $12.0 \pm 2.9$ & $3.0 \pm 1.0$ \\
\hline \multicolumn{2}{|l|}{ 血 消 } & & 3.2 & 53 & 17 & 3.2 \\
\hline
\end{tabular}

* $\mathrm{KOH}$ アルカリ変性反忘, Coの拡敬電流から蛋白波第 2 波極大までの波高

** $\mathrm{KOH}$ アルカリ変性後, SSA 除蛋白淈液のポーラロクララフ蛋白波第 2 波の波高

$* * *$ ( 泷液反応第 2 波波高 $) \div($ 第一反応第 2 波波高 $) \times 10$ によって得た值

高かった，水分且の低かった19例について，灰分量およ び有機成分量をみると，灭分量では血清より低い值を示 したものが 4 例あったが，有機成分量では血清より低い 值を示した症例はなかった。

灰分量
全症例において，最低值0.16\%，最高値1.58\%と幅か あり，また，同一種類の蛙胞でも症例によりさまさまで

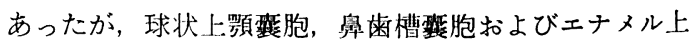
皮腫では，他の㮒胞にくらべて0.16〜0.51\%と低かった. 蛋白 
表 3 侐清および变胞内溶液の化学分析結果

\begin{tabular}{|c|c|c|c|c|c|c|c|}
\hline 瘊胞の種類 & $\begin{array}{l}\text { 婝例 } \\
\text { 番号 }\end{array}$ & 水 分 & $\begin{array}{c}\text { 有㙨成 分 } \\
(\%)\end{array}$ & 瓜 & 蛋 $\begin{array}{r}\text { 白 } \\
(\mathrm{g} / \mathrm{A})\end{array}$ & $\begin{array}{c}\text { 総ステロール } \\
(\mathrm{mg} / \mathrm{d} \boldsymbol{M})\end{array}$ & $\begin{array}{l}\text { シアル胎 } \\
(\mathrm{mg} / \mathrm{dW})\end{array}$ \\
\hline \multirow{8}{*}{ 崡 根 箦 胞 } & 1 & 83.89 & 15.30 & 0.81 & 14.6 & 345 & 708 \\
\hline & 2 & 85.37 & 13.17 & 1.46 & 11.5 & 156 & 636 \\
\hline & 3 & 88.16 & 11.10 & 0.74 & 9.4 & 127 & 288 \\
\hline & 4 & 86.29 & 13.48 & 0.23 & 12.8 & 106 & 480 \\
\hline & 5 & 90.81 & 9.01 & 0.18 & 8.7 & 99 & 476 \\
\hline & 6 & 86.88 & 11.48 & 1.28 & 7.4 & 178 & 532 \\
\hline & 7 & 88.33 & 11.35 & 0.32 & 7.0 & 198 & 492 \\
\hline & 8 & 86.44 & 12.45 & 0.71 & 6.8 & 317 & 460 \\
\hline F & 佔i & 87.02 & 12.17 & 0.72 & 9.8 & 191 & 509 \\
\hline \multirow{4}{*}{ 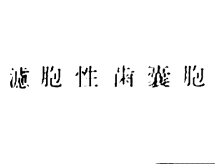 } & 9 & 88.22 & 11.06 & 0.72 & 9.1 & 382 & 536 \\
\hline & 10 & 87.16 & 12.10 & 0.74 & 9.1 & 414 & 712 \\
\hline & 11 & 87.15 & 11.27 & 1.58 & 10.6 & 255 & 544 \\
\hline & 12 & 86.51 & 13.07 & 0.42 & 12.6 & 170 & 400 \\
\hline 广: & & 87.26 & 11.86 & 0.87 & 10.4 & 305 & 548 \\
\hline \multirow{6}{*}{ 術後性: 頬部性怉 } & 13 & 86.93 & 12.09 & 0.98 & 11.4 & 337 & 516 \\
\hline & 14 & 90.10 & 9.66 & 0.24 & 8.0 & 517 & 144 \\
\hline & 15 & 88.44 & 10.73 & 0.83 & 6.3 & 110 & 408 \\
\hline & 16 & 86.72 & 12.10 & 1.18 & 9.5 & 150 & 668 \\
\hline & 17 & 90.21 & 8.87 & 0.92 & 6.4 & 50 & 228 \\
\hline & 18 & 91.56 & 7.85 & 0.59 & 6.8 & 130 & 332 \\
\hline \multicolumn{2}{|c|}{ 将坮 低 } & 88.99 & 10.22 & 0.79 & 8.1 & 216 & 382 \\
\hline 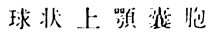 & 19 & 91.00 & 8.58 & 0.42 & 7.2 & 347 & 400 \\
\hline 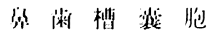 & 20 & 88.30 & 11.49 & 0.21 & 7.0 & 339 & 112 \\
\hline \multirow{2}{*}{$\begin{array}{lll}\text { カ } & >\end{array}$} & 21 & 90.55 & 8.27 & 1.18 & 6.6 & 54 & 128 \\
\hline & 22 & 89.80 & 9.62 & 0.58 & 5.4 & 106 & 92 \\
\hline \multirow{2}{*}{ エナメル上皮胢 } & 23 & 91.73 & 7.76 & 0.51 & 6.9 & 75 & 76 \\
\hline & 24 & 93.52 & 6.32 & 0.16 & 4.4 & 176 & 56 \\
\hline & 25 & 85.44 & 13.48 & 1.08 & 11.7 & 178 & 352 \\
\hline 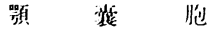 & 26 & 87.46 & 11.84 & 0.70 & 10.2 & 198 & 524 \\
\hline (分類不明の非泡) & 27 & 90.80 & 8.62 & 0.58 & 8.3 & 170 & 446 \\
\hline \multicolumn{2}{|c|}{ 平均佔 } & 87.90 & 11.31 & 0.79 & 10.1 & 182 & 441 \\
\hline \multicolumn{2}{|l|}{ 血焦 沙 } & 90.49 & 8.83 & 0.68 & 7.7 & 176 & 56 \\
\hline
\end{tabular}

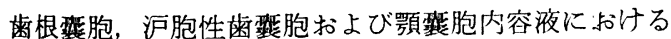
蛋白含有量は，一般に血清 $(7.7 \mathrm{~g} / \mathrm{d} l)$ より高く，ガマ腫 およびエナメル上皮腫内容液の蛋白含有量は $4.4 \sim 6.9$ $\mathrm{g} / \mathrm{d} l$ で低かった.

総ステロール

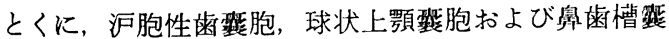
胞に执いて, $170 \sim 414 \mathrm{mg} / \mathrm{d} l$ と多量のステロールが含ま れていた．ガマ腫およびェナメル上皮腫のステロール含

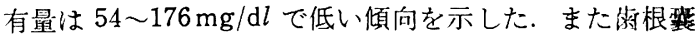
胞内容液の多く（8 例中 6 例）も $99 \sim 198 \mathrm{mg} / \mathrm{d} l$ と低い 值を示した。

シアル酸

全症例に扣いて，血清 $(56 \mathrm{mg} / \mathrm{d} l)$ よりも高濃度のシ アル酸が含まれていた。とくに高い值を示したものは，

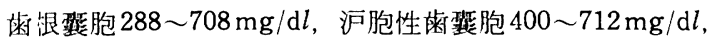
術後性頓部琵胞 6 例の うち 5 例が $228 \sim 668 \mathrm{mg} / \mathrm{d} l, 1$ 例 


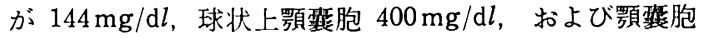
$352 \sim 524 \mathrm{mg} / \mathrm{d} l$ で, エナメル上皮腫 2 例においては， 56 および $76 \mathrm{mg} / \mathrm{d} l$ で，他の䇛胞内容液にくらべてあきら かに低い値を示した.

IV. 考察

ディスク電気泳動法は, ポリアクリルアミド・ゲルを 支持体とする電気泳動法の一種で, 極微量の, あるいは 稀薄な蛋白溶液の分画に適し，その分離能は沪紙などの 他の支持体を用いるゾーン電気泳動法よりもすぐれてい る. それにもかかわらず，ディスク電気泳動的に鼻粎槽

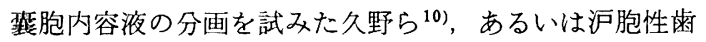

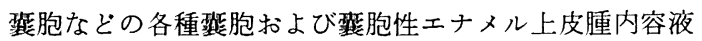
の分画を試みた金子15)の研究成績に示されているように, 蛋白成分の分離が不明瞭である. この原因として, 慗胞 内容液中には, ディスク電気泳動的に明確に分離し得な いほとに，荷電の状態拈よび分子の大きさが近接してい る蛋白成分が含まれていること，扣よび分離を妨害する 成分が共存することの 2 点が考えられる.もしも，原因 が前者にあるとすれば, 䍌胞内容液中の蛋白濃度は, か なり高くなるはずであるが，久木田ら年ををはじめとする 諸家の研究によると, 各種裂胞内容液の総蛋白濃度は血 清に近いと報告している. したがって，蛋白成分分離不 良の原因は後者にあり，主として糖蛋白 (mucin) の影響 が大きいと考えた，そこで，裂胞内容液を一旦一 $20^{\circ} \mathrm{C} の$ 冷暗所に凍結保存したのち, これを室温で解凍し, mucin などの不溶成分を遠心分離して除去してから，ディスク 電気泳動に供することを試みた.

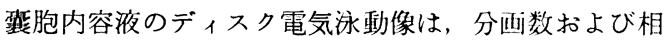
対濃度において，正常血清の泳動像と同じょうな所見を 示すものと，血清とは異なる特異な泳動像を示すものと に大別することができる.

血清型の泳動像を示した症例は，歯根整胞において 8 例中 3 例に, 沪胞性菡雚胞, 術後性頓部整胞および診断 の確定しなかった罘霆胞に打いて各 1 例ずつみとめられ た。

非血清型の泳動像をみると，一般に globulin 位にお ける分画数扣よび浱度の減少, transferrin の減少执よ び haptoglobin 画分の減少などが，著明な変化としてみ とめられたが， transferrin の前に泳動する 2 つの画分

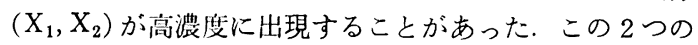
画分は, Morse $5^{22}$ が歯根缼胞と幽根肉芽腫の鑑別診 断を目的として，歯根尖端部俢出液のディスク電気泳動 を試みた結果見出した，ceruloplsamin 分画带の extra bands と易動度がほぼ一致する，炎症性疾患の患者の血 清に ceruloplasmin が增加することがしられているが， この 2 つの画分は, 整胞壁組織の炎症性変化の結果. 内 容液中に一洔的に出現してきたものとも考えられる.

襄胞の種類别に，泳動像の特微を把握することはでき
なかった. 分析例数が少なかったにせよ，襄胞内容液の ディスク電気泳動所見を，臨床的鑑别診断に利用するこ との意義は少ないと考える，むしろ，各症例の泳動像は，

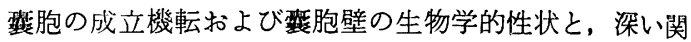
係を有しているものと考える.

歯根琵胞に打いて，多くの場合，血清型の泳動像を示 し，また，albumin 分画の減少が症例の多くにみとめら れなかった珪由, および，術後性煩部襄胞の 2 例（症例 17，18）において slow $\alpha_{2}$ および $\beta$-globin が消失し た琹由など，さらに検討されるべき問題である.

䍿胞内容液は、コバルトを含む塩化アンモンーアンモ ニア緩衝液中に抏いて,いわゆるBrdičkaの「蛋白波」 を示した。

波形は，一般に血清と同型で， -1.1 volt 付近のコバ ルト波にひき続き， -1.4 および -1.6 volt 付近に $2 つ$ の極大波（第 1 波打よび第 2 波）を生じた，沪胞性函露 胞の 4 例中の 2 例, 球状上顎㷼胞 1 例, およびェナメル 上皮腫 2 例の内容液は，血清とは異なる特異な波形を示 した. とくに，エナメル上皮腫の蛋白波は，他の整胞と はあきらかに異なる特異な波形を示し，蛋白波のみに拉 いて, 本症を他の装胞と区別し得る可能性が示された(図

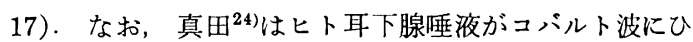
き続き，第1波が抑制され，第 2 波が高い特異なポーラ ログラムを示すことを見出したが，䡛胞内容液でこれに 類似した波形を示したものはなかった。 また，ガマ腫内 容液の蛋白波は，哞液蛋白波よりも，むしろ血清あるい は albuminの蛋白波に近い形状を示した。

電解液中に打ける裴胞内容液の濃度を変化させて, 蛋 白波の交文効果を観察すると，エナメル上皮腫では，交 叉効果がみとめられず，ポーラログラフ的性質に扎いて，

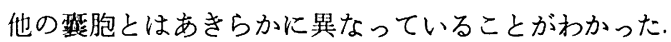
第 1 波拈よび第 2 波の举動は，症例によりさまざまであ

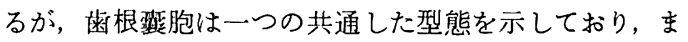
た，交叉点が比較的高い蛋白濃度にあるので，他の慗胞 とは区別し得ると考えられる.

第一反応扣よび沪夜反応の結果は, 各症例によってさ まざまであり，また，例数が少ないために，翌胞の種類 による特徵を見出すことは囦蜼であった，これは，整胞 内容液の蛋白濃度の差が, 症例により著るしく巽なるた めである.

これに対して，同一条件で記録して得た第一反応およ び汇液反応の第 2 波の波高の比,すなわち, “protien index”は, 蛋白濃度の影響を受けずに, 主として, 蛋白 成分の性状によって変化するものであることから，実験 結果（図36）に示したように，釷胞の種類別による特徵 が比較的明瞭に表示されることがわかった.すなわち，

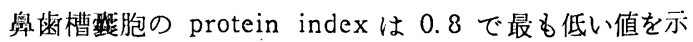
し，エナメル上皮腫は 10１0.5 で最も高い值を示し て，他の胞とはあきらかに区別することができた．料 


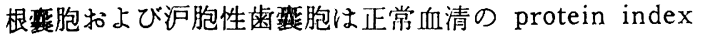
より，わずかに低い值を示し，球状上䫇聚胞拈よびガマ 腫は, 血清と近似值か, あるいは, わずかに高い値を示 した。

蛋白波は分子中に含まれる SH 基によって与えられる と考えられているが，その発生機構の詳細は不明である. しかし，蛋白の種類により，また，同一種類の蛋白にお いても性状の変化によって, 特異な波形を示し, 蛋白溶 液の性質をあらわす一つの指標として好適である. 医学 領域では，すでに癌の診断への応用の途がひらかれてい る. 血清を検体とした，諸家の癌反応の臨床成績をみる と，第一反応で $71 \sim 100 \%$ の陽性率が，また，沪液反応 で76. 2〜100\%の陽性率が得られている ${ }^{25)}$.

褧胞内容液の場合は，内容液の水分，有機成分，灭分， 蛋白, 総ステロール执よびシアル酸の定量結果にみられ るよらに, 各成分の含有量のばらつきが大きいので, 蛋 白波の形状, 交叉効果, 第一反応, 沪液反応拈よび protein indexのどれか一項目だけをとりあげて, 臨床的鑑 別診断法として応用することは危険である. しかし，こ れら数項目の方法を組合わせて，総合的に検討するとき， ポーラログラフ法はすぐれた㘕別診断法の一つとして役 立つ可能性がある.

今回は, ディスク電気泳動分画に供した材料の一部を 用いたため, 凍結・融解処理の影響が，かなり大きくあ らわれているものと考えられる. 今後, 新㙰な材料につ いて症例をかさねつつ，ポーラログラフ的鑑別診断法の 意義について研究する予定である.

整胞内容液の水分量は, 笑験結果において示したよう に，一般に血清より低く，有機成分に富むが，この水分 量の低下は，主に有機成分の含有量と関係が深い，有機 成分の大部分は蛋白であり，有機成分に対する蛋白の割 合を表 3 ，から求めると，正常血清では約 $87 \%$ であるが， 慗胞内容液では56\%（症例22）から96.4\%（症例12）ま で幅広く変動していた，蛋白の占める割合が小さかった 症例において, シアル酸の定量值が高かったものは, 糖 蛋白，とくに mucin の濃度が高いと推定される. シア ル酸および総ステロール含有量の低い症例では, 霡胞壁 組織や血液成分に由来する細胞成分が多く含まれていた 可能性がある.

エナメル上皮腫内容液に打けるシアル酸含有量は，他 の整胞内容液にくらべて著明に低い值を示した，この成

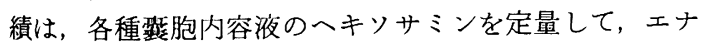
メル上皮腫内容液のヘキソサミン含有量が，とくに低い ことを報告した金子(15)の成績によく一致している．エナ メル上皮腫内容液は, ディスク電気泳動像扣よび蛋白波 の挙動においても特異であった。これは，エナメル上皮

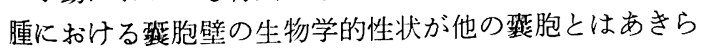
かに異なっているためであると考えられるが，また，工 ナメル上皮腫形成に対する生体の反応峨式が，他の留胞
とは基本的に異なっているものと考えられる。

㢣胞壁の生物学的性状との関係, および㖉胞の存在に 対して, 生体がどのように反応しているかなど, 大いに 注目されるところである.

$$
\text { V. 結語 }
$$

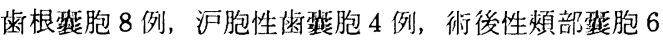

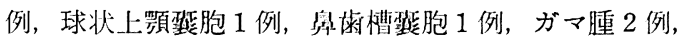
㮒胞性エナメル上皮腫 2 例および診断の確定しなかった 顎垔胞 3 例の, 合計 27 例から得た垬胞内容液について, ディスク電気泳動法による蛋白組成，およびポーラログ ラフィーによる電気的特性について検索し, 同時に, 水 分, 有機成分, 灰分, 総蛋白, 総脂質およびシアル酸の 定量を扣こさない，以下の結果を得た

1）ディスク電気泳動的に分画した，壁胞内容液の蛋 白組成は, 血清類似の泳動像を示す血清型, と血清とは 異なる特異な泳動像を示す非血清型に大別することがで きる。

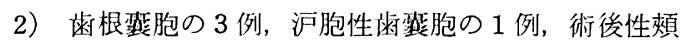
部翼胞の 1 例および顎裂胞の 1 例が血清類似の泳動像を 示し, 他の症例は血清とは異なる特異な泳動像を示し た。

3）非血清型の泳動像では, globulin 位における分画 数および濃度の減少, さらに transferrinの減少が著明 な変化としてみとめられた。

4）歯根琵胞の 3 例, 沪胞性函㗺胞の 1 例, 術後性頓

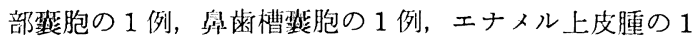
例および顛琵胞の 1 例において, transferrin と albumin の間に泳動する 2 つ画分 $\left(X_{1}, X_{2}\right)$ が出現, もしくは特 異的に増加した。

5）篗胞の種類別による泳動像の特徽を把握すること は困難で, ディスク電気泳動法による臨床的鑑別診断の 意義はみとめられなかった。

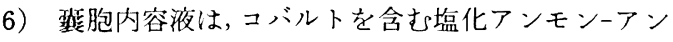
モニア緩衝液中に拈いて，Brdička の「蛋白波」を示し た.

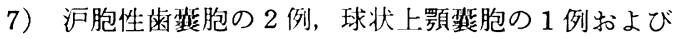
エナメル上皮腫の 2 例は, 血清とは異なる特異な蛋白波 を示した.

8）鼠胞内容液の蛋白波は，一般に交叉効果を示すが， エナメル上皮腫内容液は交叉効果を示さなかった.

9）交攴効果に拈ける第 1 波および第 2 波の挙動と交 必点は, 雔胞の種類別による特改を, 比較的明瞭にあら わしていた。

10）第一反応扣よび沪液反応において，各種焣胞内容 液の第 2 波の波高はさまざで, 弉胞の種類別による特 徵は見出されなかった。

11）Protein index は，挃胞の種類別による特徵を比 較的明瞭にあらわしていた。 
12）蛋白波の形状，交叉効果，第一反応および沪液反 応を総合的に検討することにより，ポーラログラフ法が 鑑別診断法として役立つ可能性が示唆された.

13）哫胞内容液の水分量は, 症例により多様に変化し ているが，一般に血清より低く，有機成分に富んでいた 有機成分としては, 蛋白の占める割合が大きかった.

14）エナメル上皮腫内容液に打いて，シアル酸がきわ めて少なかった。

稿を終るに当たり，御指導，御校閲をいただいた西村恒一教授 ならびに其田一男教授に深謝いたします。また本研究遂行にあた り御協力くださった日本歯科大学歯学部ならびに新渴歯学部の 口腔外科学教室, 口腔生化学教室, 口腔病理学教室の諸氏に感謝 の意を表します。

\section{文献}

1）深江一：口腔底二発生セル所謂 Epidermoidcyste ノ一 例, 站二其内容/化学的検査. 耳楀咽喉科 $4: 372 \sim 373$ 1931.

2）有本和男，滝竜人：口腔底皮㥞㡭胞の 2 例について．臨 本歯科学報 1:18 19 1946 .

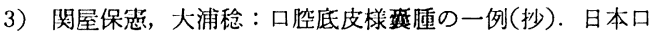
㛊外科学会雑誌 $2: 123 \sim 1241956$.

4）形浦昭克, 西野目雅晴, 川口栄三：喉頭蓋に発生した Epidermoid cyst $の 1$ 例一特に亦胞内容液の脂質分画 について一。耳舆臨床 $59: 48 \sim 521966$.

5）久野吉婎, 束理十三雄，今村美智子，土持綱太郎，佐臀

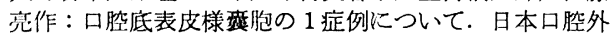
科学会雑誌 $14: 141 \sim 1441968$.

6）長谷川明，束理十三堆，上原淳，本多洋之，比芸実盛， 園山年：乳児に見られた大きな口腔底皮㥞磁胞の 1 例. 日本口䶼外科学会雑誌 18:187 191 1972.

7）鉿木貢：口腔底の類皮梯胞の 1 例一その病理像之内容 液の性状について一。日本口腔外科学会雑誌 $19: 638$ 6471970.

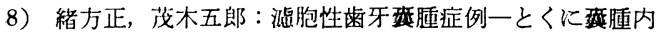
容液の蛋白分画について一。耳舆臨床 $57: 411 \sim 415$ 1964.

9）茂木五郎，中村正二郎，麻上義文：ディスク泳動法によ 万諸体液蛋白の分析. 生物物理化学: $11: 15 \sim 221964$.
10）久野吉雄, 束理十三堆, 大泉昌子, 斎藤光弘：奥歯槽轱 胞の 2 症例について. 日本口腔外科学会䧴誌 $16: 406 \sim$ 4101970.

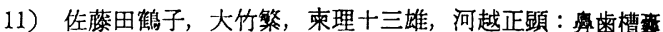
胞の一症例. 日本口腔外科学会雑誌 $19: 100 \sim 1031973$.

12）吉田滋美：頑骨内に発生する葓胞の生成機序に関する生 化学的研究. 歯科学報 $62: 97 \sim 1051962$.

13) Toller, P.A. : Origin and Growth of Cysts of the jaws. Ann. R. Coll, Surg 40:306-336 1967.

14) Vickery, L.M., Darling, A.I. : An unusual maxillary cyst. OS OM \& OP $31: 328-3301971$.

15）金子刑夫：䫇胞内容液に関する生化学的研究. 日本口 热外科学会雑誌 $18: 2 \sim 141972$.

16）鈴木貢：顠骨变胞壁の赤外線吸収スペクトル，日本口腔 外科学会雑誌 $19: 23 \sim 281973$.

17) Ornstein, L. and Davis, B. J. : Disc-electrophoresis (Preprinted by Distillation Products Industries, Eastman Kodak Co.), 1962.

18) Tropp, C., Jühling, L. und Geiger, F. : Polarographische Eiweiß-untersuchungen. III. Albumin, Globulin, Fibrinogen und Serum. Z. Physiol. Chem 262: 199-209 1939.

19）鈴木德四郎，竹原靖明，佐藤恵宣，関正一郎，飯島興 治：唾液シアル酸の呈色反応について. 歯学 $51: 26 \sim$ 311963.

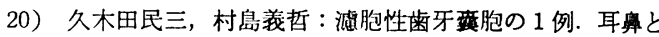
臨床 $7: 23 \sim 271961$.

21) Schneyer, L.H. : Coagulation of salivary mucoid by freezing and thawing of saliva. Proc Soc Exp Biol \& Med $91: 565-5691956$.

22) Morse, D.R., Patrik, J.W. and Schactele, G.R. : Electrophoretic differentination of radicular cysts and granulomas. OS OM \& OP $35: 249-2641973$.

23) Brdička, R. : Polarographic studies with the dropping mercury cathode Part XXXI. A new test for proteins in the presence of cobalt salts in ammonium chloride. Collection $5: 112-1181933$.

24）真田一男：ポーラログラフ法による唾液タンパクの研究 （I）上卜各種唾液タンパク波の特徵. 生化学 $34: 99$ $\sim 1051962$.

25）館勇(編)：ポーラログラフィー，岩波書店，東京，1958， p402 410. 